\title{
Temperature modulates PVN pre-sympathetic neurones via transient receptor potential ion channels.
}

Fiona O'Brien ${ }^{1}$, Claire Feetham ${ }^{1}$, Caroline Staunton ${ }^{1}$, Katharine Hext ${ }^{1}$ and Richard BarrettJolley ${ }^{1}$.

${ }^{1}$ Institute of Ageing and Chronic Disease, University of Liverpool, United Kingdom.

\begin{abstract}
Background and purpose: The paraventricular nucleus (PVN) of the hypothalamus plays a vital role in maintaining homeostasis and controls cardiovascular function via autonomic pre-sympathetic neurones. We have previously shown that coupling between transient receptor potential cation channel subfamily $V$ member 4 (Trpv4) and small-conductance calcium-activated potassium channels (SK) in the PVN facilitate osmosensing. TRP channels are also thermosensitive and therefore, in this report we investigated the temperature sensitivity of PVN neurones.
\end{abstract}

Experimental approach: We identified TRP channel mRNA in mouse PVN using quantitative reverse transcription-PCR (RT-PCR). Using cell-attached patch-clamp electrophysiology, we characterised the thermosensitivity of Trpv4-like ion channels on mouse PVN neurones. Following recovery of temperature sensitive single channel kinetic schema, we constructed a novel and predictive stochastic mathematical model of these neurones. We then validated this model with electrophysiological recordings of action current frequency from mouse PVN neurones.

Results: We identified 7 TRP channel genes in the PVN with known thermosensitive capabilities. Trpv4 was the most abundant of these and was easily identified at the single channel level using cell-attached patch-clamp electrophysiology on PVN neurones. We investigated the thermosensitivity of these Trpv4-like channels; open probability (Po) markedly decreased when temperature was decreased, mediated by a decrease in mean open dwell times. Our neuronal model predicted that PVN spontaneous action current frequency (ACf) would increase as temperature is decreased and in our electrophysiological experiments, we found that ACf from PVN neurones was significantly higher at lower temperatures. The broad-spectrum channel blocker, gadolinium (100 $\mu \mathrm{M})$, was used to block the warm-activated $\mathrm{Ca}^{2+}$-permeable Trpv4 and Trpv3 channels. In the presence of gadolinium $(100 \mu \mathrm{M})$, the temperature effect was largely retained. Using econazole $(10 \mu \mathrm{M})$, a blocker of Trpm2, we found there were significant increases in overall ACf and the temperature effect was inhibited. 
Conclusion: Our work identified Trpv4 mRNA as an abundantly expressed thermosensitive TRP channel gene in the PVN and this ion channel contributes to the intrinsic thermosensitive properties of PVN neurones. At physiological temperatures $\left(37^{\circ} \mathrm{C}\right)$, we observed relatively low ACf primarily due to the activity of Trpm2 channels, whereas at room temperature, where most of the previous characterisation of PVN neuronal activity has been performed, ACf is much higher, and appears to be predominately due to reduced Trpv4 activity. This work gives insight into the fundamental mechanisms by which the body decodes temperature signals and maintains homeostasis.

\section{Introduction}

Prolonged deviation in core body temperature $\left(T_{c}\right)$ outside a narrow range results in serious physiological issues incompatible with life, and therefore, it is tightly regulated by a homeostatic system (Gomez, 2014; Morrison \& Nakamura, 2011). Changes in environmental temperature produce reflex responses to maintain $\mathrm{T}_{\mathrm{c}}$ in an optimal range (Kanosue et al., 1991; Kanosue, Yanase-Fujiwara \& Hosono, 1994), however, how the brain coordinates such responses is a longstanding and unresolved question.

Early models of temperature regulation were based around the existence of a central integrator comprised of hypothalamic neurones that orchestrate homeostatic responses around a set-point temperature (H T Hammel \& Pierce, 1968; Hardy, 1961). An alternative theory proposes that the brain has no central integrator for $T_{c}$ but instead, various thermoregulatory effectors are thought to be regulated independently, giving the appearance of coordinated action without the existence of a single so-called 'controller' (McAllen, Tanaka, Ootsuka \& McKinley, 2010; Romanovsky, 2007a; Satinoff, 1978). Central nervous system (CNS) level control of $T_{c}$ is mediated by a combination of negative feedback and feed-forward mechanisms that share common peripheral thermal sensory inputs (Kanosue, Crawshaw, Nagashima \& Yoda, 2010; Morrison \& Nakamura, 2011). Feedback responses are those that are triggered when $T_{c}$ deviates away from the optimal range, for example, exercise induces an increase in $T_{c}$ by several degrees Celsius (Fuller, Carter \& Mitchell, 1998; Walters, Ryan, Tate \& Mason, 2000). Feed-forward mechanisms on the other hand, are preventative, and are triggered prior to any change in core temperature. The most common feed-forward example is the detection of change in air temperature (by thermoreceptors in the skin) which trigger thermoregulatory responses that prevent any significant change in $T_{c}$ (Nakamura \& Morrison, 2008; Nakamura \& Morrison, 2010; Romanovsky, 2014). The hypothalamus contains the primary integrative and rostral efferent components of these circuits, but local thermal stimulation of other areas in the CNS, including several brain-stem neuronal groups and the spinal cord also trigger autonomic thermoeffector responses. Thermosensitive neurons in the preoptic area (POA) of the hypothalamus have been the most studied to date (Kanosue et al., 1991; Kanosue, YanaseFujiwara \& Hosono, 1994; Kazuyuki, Hosono, Zhang \& Chen, 1998; Nagashima, Nakai, Tanaka \& Kanosue, 2000; Nakamura \& Morrison, 2010; Romanovsky, 2007b). 
Early experiments showed that stimulation (warming) of the cat (Hemingway, Forgrave \& Birzis, 1954; Magoun, Harrison, Brobeck \& Ranson, 1938) and rat (Carlisle \& Laudenslager, 1979) POA could trigger dramatic thermoregulatory responses that were similar to those observed by heating the entire animal. Cooling of the POA promotes vasoconstriction, BAT thermogenesis and shivering in dogs and baboons (Gale, Mathews \& Young, 1970; Hammel, Hardy \& Fusco, 1960) and results in baboons signalling for rapid heat reinforcement. Lesioning of the cat POA has been shown to abolish thermoregulatory responses in animals subjected to temperature challenge (Clark, Magoun \& Ranson, 1939; Teague \& Ranson, 1936). Direct sensing of changes in skin temperature has been shown to activate POA efferent signals that control thermal effector organs (Morrison, 2016; Morrison, Madden \& Tupone, 2014). Electrophysiological studies have characterised the intrinsic temperaturesensitive properties of POA neurones in rabbit (Boulant \& Hardy, 1974), rat (Baldino \& Geller, 1982; Hori, Nakashima, Hori \& Kiyohara, 1980) mice (Tan et al., 2016) and dogs (Hardy, Hellon \& Sutherland, 1964). However, there have also been many reports of temperature sensitive neurones outside of the POA (Edinger \& Eisenman, 1970; Kobayashi \& Murakami, 1982; Nakayama \& Hardy, 1969; Simon \& Iriki, 1970; Wünnenberg \& Hardy, 1972). The neuronal circuitry and projections of the POA are not fully understood but several additional brain regions including the dorsomedial hypothalamus (DMH), the paraventricular nucleus of the hypothalamus (PVN), and the raphe pallidus nucleus have been proposed to act alongside the POA to regulate $\mathrm{T}_{\mathrm{c}}$ (Morrison, 2016; Morrison, Madden \& Tupone, 2014; Zhao et al., 2017). The DMH is also recognised as another key player in thermoregulation (Dimicco \& Zaretsky, 2007; Heeren \& Münzberg, 2013; Morrison \& Nakamura, 2011) and stimulation of rat DMH neurons was shown to increase in BAT sympathetic nerve activity (SNA), BAT temperature and Tc (Cao, Fan \& Morrison, 2004; de Menezes, Zaretsky, Fontes \& DiMicco, 2006; Zaretskaia, Zaretsky, Shekhar \& DiMicco, 2002).

Several studies using cFos as a marker of activation have shown that mouse PVN neurones respond to both warm and cold ambient temperature change (Bachtell, Tsivkovskaia \& Ryabinin, 2003; Bratincsák \& Palkovits, 2004). Exposure to a hot environment $\left(39^{\circ} \mathrm{C}\right)$ increased cFos expression of rostral ventrolateral medulla (RVLM) -projecting (Cham \& Badoer, 2008) and spinally-projecting neurones in the rat PVN (Cham, Klein, Owens, Mathai, McKinley \& Badoer, 2006). Anatomical studies using transneuronal viral tracing approaches show that post injection of pseudorabies virus into the rat tail, within the hypothalamic area, the majority of labelled neurons were located in the PVN (Smith, Jansen, Gilbey \& Loewy, 1998). Injection of glutamate in the PVN leads to an increase in interscapular brown adipose tissue (IBAT) temperature in rats and on the other hand, lesioning of the PVN reduced febrile-evoked increases in body temperature, suggesting a role for the PVN in driving sympathetic outflow to BAT, at least in the context of fever (Amir, 1990; Caldeira, Franci \& Pelá, 1998; Horn, Wilkinson, Landgraf \& Pittman, 1994; Leite, Zheng, Coimbra \& Patel, 2012; Lu et al., 2001). Furthermore, more generally, Cabral et al., (2012) showed that TRH (a neuropeptide necessary for cold-induced thermogenesis) -neurones in the rat PVN 
are activated when animals are exposed to short-term cold conditions (Cabral, Valdivia, Reynaldo, Cyr, Nillni \& Perello, 2012).

Electrophysiological studies have been pivotal to not only characterising the biophysical profile of PVN neurones, but also understanding how the PVN plays a role in the regulation of homeostatic functions. The PVN is typically divided into the parvocellular and magnocellular regions, which both have many subdivisions (BÜTtner-Ennever, 1997; Koutcherov, Mai, Ashwell \& Paxinos, 2000) but in its most simplistic representation, the PVN is divided loosely into the parvocellular area, posterior magnocellular lateral area and the intermediocellular region (dorsal and PVN) where pre-autonomic neurones are most abundant (Chen, Gomez-Sanchez, Penman, May \& Gomez-Sanchez, 2014; Feetham, O'Brien \& Barrett-Jolley, 2018; Kiss, Martos \& Palkovits, 1991). To date, three distinct electrophysiological phenotypes have been described in PVN neurones (reviewed in Feetham et al., (2018)); magnocellular (type I) PVN neurones have phasic bursting patterns and express a rapidly inactivated, or "A-type," potassium conductance (Sonner \& Stern, 2007; Tasker \& Dudek, 1991). Parvocellular (type II) PVN neurones express a slowly inactivating delayed rectifier potassium conductance and it is suggested that the differences between types I and II cells may be explained by differential expression of voltage-gated potassium and calcium channels (Luther, Daftary, Boudaba, Gould, Halmos \& Tasker, 2002). Furthermore, in the parvocellular area, there appears to be two different neuronal phenotypes; (1) exhibiting electrophysiological properties similar to neuroendocrine magnocellular cells (Stern, 2001; Tasker \& Dudek, 1993) and (2) pre-autonomic/spinally projecting neurones which show neurones a slowly inactivating potassium conductance (Barrett-Jolley, Pyner \& Coote, 2000; Tasker \& Dudek, 1993). In regards to thermosensitivity, Inenaga et al., (1987) was the first study to confirm the inherent thermosensitivity of PVN neurones and characterised separate intrinsically "cold-sensitive" and "warm-sensitive" neurones (Inenaga, Osaka \& Yamashita, 1987). To our knowledge, this is the only electrophysiological study investigating the temperature sensitivity of PVN neurones, and to date, there has been no molecular characterisation.

The cellular pathways involved in thermo-sensation are well conserved and consist of a set of specialised temperature-gated ion channels that are highly sensitive to a wide range of hot and cold temperatures. The thermo-transient receptor potentials (TRPs), a recently discovered family of ion channels activated by temperature, are expressed in primary sensory nerve terminals where they provide information about thermal changes in the environment. There are 4 heat thermo-sensitive TRP ion channels; Trpv1 (activated with temperature $>43^{\circ} \mathrm{C}$ ) (Everaerts et al., 2011), Trpv2 (activated with temperature $>52^{\circ} \mathrm{C}$ ) (Liu \& Qin, 2016), Trpv3 (activated with temperature $>32^{\circ} \mathrm{C}$ ) (Peier et al., 2002) and Trpv4 (activated with temperature $>27^{\circ} \mathrm{C}$ ) (Güler, Lee, lida, Shimizu, Tominaga \& Caterina, 2002) . In addition, there are 2 identified cold thermo-sensitive TRP ion channels; Trpm8 (activated with temperature $<28^{\circ} \mathrm{C}$ ) (McKemy, Neuhausser \& Julius, 2002) and Trpa1 (activated with temperature $<17^{\circ} \mathrm{C}$ ) (Laursen, Bagriantsev \& Gracheva, 2014). PVN ion channels, including 
those that are thermo-sensitive have recently been summarised in (Feetham, O'Brien \& Barrett-Jolley, 2018).

We have previously shown that Trpv4 is expressed on PVN neurones of CD1 mice (Feetham, Nunn \& Barrett-Jolley, 2015; Feetham, Nunn, Lewis, Dart \& Barrett-Jolley, 2015). Originally, these channels were considered sensors of cell volume (Liedtke et al., 2000) and in the PVN, we have shown that Trpv4 channels functionally couple to a subtype of $\mathrm{Ca}^{2+}$-activated $\mathrm{K}^{+}$ channel (SK channel) to sense changes in osmolality, probably mediated by subtle changes in cellular volume (Feetham, Nunn, Lewis, Dart \& Barrett-Jolley, 2015). We also found that ICV injection of hypotonic artificial cerebrospinal fluid (ACSF) into CD1 mice decreased mean blood pressure, but not heart rate and this effect was abolished by treatment with the Trpv4 inhibitor RN1734 (Feetham, Nunn \& Barrett-Jolley, 2015). In another recent study, we found that systemic administration of the highly selective lipid-soluble Trpv4 antagonist GSK2193874 resulted in tail blood-flow dynamics that were in-compatible with a local (vascular smooth muscle or endothelial cell) mechanism (O'Brien, Staunton \& Barrett-Jolley, 2021). Accumulating data shows that Trpv1 may play a role in regulating sympathetic outflow in hyperthermic responses, but in the light of the above data, we hypothesised that PVN Trpv4 ion channels also play a role in thermoregulation (Alawi et al., 2015).

Many studies have shown that Trpv4 can also be activated by heat $>25^{\circ} \mathrm{C}$ (Clapham, 2003; Güler, Lee, lida, Shimizu, Tominaga \& Caterina, 2002; Watanabe, Vriens, Suh, Benham, Droogmans \& Nilius, 2002) as well as mechanical stimuli. Trpv4 immunoreactivity is present in a number of brain regions known for producing thermoeffector responses including the POA (Güler, Lee, lida, Shimizu, Tominaga \& Caterina, 2002), the PVN (Feetham, Nunn \& Barrett-Jolley, 2015) but also in the vasculature where its activation produces vasodilation (Filosa, Yao \& Rath, 2013).

Therefore, the aim of this study was to characterise the thermosensitivity of a subpopulation of PVN neurones; we have already shown that Trpv4 channels are present in the PVN but here, we used RT-PCR to identify additional thermosensitive targets. We pharmacologically identified Trpv4-like channels from PVN neurones and characterised their intrinsic thermosensitive properties at the single-channel level. We built on from our previous mathematical model to predict that neuronal activity should increase as temperature is decreased; we validate this model with recordings from PVN neurones. We show that the temperature-sensing capabilities of PVN neurones is complex, and is likely to involve multiple ion channels, including Trpv4, Trpv3 and another known thermosensitive ion channel, Trpm2. 
bioRxiv preprint doi: https://doi.org/10.1101/2022.01.26.477880; this version posted January 28, 2022. The copyright holder for this preprint (which was not certified by peer review) is the author/funder, who has granted bioRxiv a license to display the preprint in perpetuity. It is made available under aCC-BY-NC-ND 4.0 International license. 


\section{Methods}

\section{Animals}

Mice were housed at $22-24^{\circ} \mathrm{C}$ in a $12 \mathrm{~h}$ light/dark cycle-controlled facility with ad libitum access to food and water. Animals were sacrificed by Schedule 1 methods for all in vitro work and all experiments were approved by the Home Office, UK.

\section{Quantitative PCR}

Young (6-8 months) and old (24 months) mice were killed by Schedule 1 methods and the general hypothalamic area was blocked and transversely sliced with $600 \mu \mathrm{M}$ thickness. The PVN was identified using the third ventricle and fornix as markers and was punched out using a $1.5 \mathrm{~mm}$ biopsy punch. PVN punch biopsies were suspended in $14 \mu \mathrm{L}$ of RNA-free water and homogenised by passing the lysate through 20-gauge needle multiple times. To obtain the required volume of mRNA, samples were pooled, with between 2-3 PVN punch biopsies per $14 \mu \mathrm{L}$ of RNA-free water. RNA extraction was carried out using the RNeasy Plus Micro kit, together with gDNA eliminator and MinElute spin columns (Qiagen, UK) and analysed for concentration, purity and quality using the NanoDrop ${ }^{\mathrm{TM}} 2000$ (Thermo Scientific, UK). cDNA synthesis (mRNA) was performed using the RT2 First Strand kit (Qiagen, NL) according to the manufacturer's protocol. Using the Neuronal ion channel plate (Qiagen, UK), 84 ion channels as well as housekeepers were measured in each sample. qPCR analysis was performed using the Stratagene MX3000P RT-PCR System (Stratagene, La Jolla, $\mathrm{CA}$ ) in a $25-\mu \mathrm{L}$ reaction mixture. Expression relative to mean of 3 housekeeper genes (Actb, Ldha, Rplp1) Cts for that sample is presented as the $\Delta \mathrm{Ct}$.

\section{Brain slice preparation}

CD1 mice of both sexes, aged 2-3 weeks were killed by Schedule 1 methods and the brain was swiftly removed and placed in ice-cold low $\mathrm{Na}^{+} /$high-sucrose artificial cerebrospinal fluid (ACSF) and sliced as previously described (Feetham, Nunn, Lewis, Dart \& Barrett-Jolley, 2015). In brief, coronal PVN slices were prepared using a Campden Instruments Ltd Leica VT1000S and stored in a multiwell dish containing physiological ACSF. Slices were kept at 35$37{ }^{\circ} \mathrm{C}$ with continuous perfusion of $95 \% \mathrm{O} 2 / 5 \% \mathrm{CO} 2$ and left to recover for at least $1 \mathrm{hr}$ before recording.

\section{Electrophysiology}

Thick-walled patch-pipettes were fabricated using fire-polished $1.5 \mathrm{~mm}$ o.d. borosilicate glass capillary tubes (Sutter Instrument, Novato CA, USA) using a two-step electrode puller (Narishige, Japan). Neurons were visualised using a Hitachi KP-M3E/K CCD camera attached to a Nikon Eclipse microscope with an effective magnification of $\sim 1000 x$. Cell-attached patch clamp electrophysiology was performed as previously described using an Axopatch 200b amplifier (Molecular Devices Axon Instruments, USA) (Feetham, Nunn, Lewis, Dart \& Barrett-Jolley, 2015). For spontaneous action current recordings, analogue data were 
further amplified with a Tektronix FM122 (Beaverton, OR, USA) AC-coupled amplifier. The temperature of the recording bath was maintained using the npi electronic TC-10 (Scientifica, UK). In all cases, data were low-pass filtered at $1 \mathrm{kHz}$ and digitised at $5 \mathrm{kHz}$ with a Digi Data 1200B interface. Recording solutions are described below and junction potentials were calculated using JpCalc (Barry \& Lynch, 1991).

\section{Analysis of electrophysiological recordings}

Single channel recordings were digitally filtered at $1 \mathrm{kHz}$ in WinEDR (University of Strathclyde, UK). Open and closed levels were assessed by all-points amplitude histograms and were used to create current-voltage (IV) curves. Single channel events were idealized using the segmental K means (SKM) methods (Qin, 2004) using QuB software (SUNY, Buffalo, NY) and open probability (Po) was determined from the idealised record as previously described (Lewis et al., 2013). For dwell time analysis, dead-time was set to three sample intervals $(0.3 \mathrm{~ms})$ and recordings where only a single channel was gating were used. Open and closed dwell times were log binned according to the methods of (Sigworth \& Sine, 1987) and fitted with an exponential log probability density function (pdf) in Clampfit 10.3 (Molecular Devices, Sunnydale California). The number of time constants for each distribution was determined using a log-likelihood ratio test in Clampfit 10.3 at a confidence level of $\mathrm{P}=0.95$.

Individual sets of model kinetic rates were obtained by fitting the idealised data using the MIL algorithm implemented in QuB. Missed events during maximum interval likelihood (MIL) rate optimisation were automatically accounted for in QuB by computation of a corrected Q matrix in the MIL algorithm.

Analysis of action current frequency was performed using WinEDR for acquisition of data and then a custom program designed to detect action currents based on an adaptive threshold routine.

\section{Solutions}

Cell-attached patch recordings were made using the following solutions: ACSF composition (mM): $127 \mathrm{NaCl}, 1.8 \mathrm{KCl}, 1.2 \mathrm{KH}_{2} \mathrm{PO} 4,2.4 \mathrm{CaCl}_{2}, 1.3 \mathrm{MgSO}_{4}, 26 \mathrm{NaHCO}_{3}$ and 5 glucose. Pipette solution for action current and single channel recordings composition (mM): $35 \mathrm{KG}$; $5 \mathrm{KCl} ; 100 \mathrm{NaCl}$ and $10 \mathrm{HEPES}(\mathrm{pH} \mathrm{7.4)}$ with $\mathrm{NaOH}$. All experiments were performed in the daytime (11:00-17:00 h) to limit the effects of circadian rhythm on activity of the cells used (Belle, Diekman, Forger \& Piggins, 2009).

\section{Design of the computer model}

Mathematical models were constructed in Python using open-source NEURON libraries (Hines \& Carnevale, 1997a; Hines, Davison \& Muller, 2009). Our model was based on that of Feetham et al., 2015 (Feetham, Nunn, Lewis, Dart \& Barrett-Jolley, 2015); in brief, inputs 
arise from both excitatory 'Netstim' neurones and inhibitory interneurons, see Fig. 5A. The interneurones are also driven by excitatory 'Netstim' neurones. Since computer power has increased significantly, the model has been updated in several ways: (a) The new model uses stochastic channels rather than "density" (deterministic equations), since the noise added by stochastic simulation allows for more authentic simulation (Cannon, O'Donnell \& Nolan, 2010). To obtain single channel rate constants for Kv channels we fitted our wholecell Kv data using a Monte Carlo bootstrap approach within Python. Netstim activities are also now scattered stochastically around the fixed means previously used by Feetham et al., 2015 (Feetham, Nunn, Lewis, Dart \& Barrett-Jolley, 2015). (b) We replaced osmotic sensitive Trp4 with temperature sensitive channels, using our experimentally measured rate constants, stochastic model and conductance, see (Fig. 5A). Temperature dependence was included by applying Q10 to each of the forward rate constants. We also added stochastic SK channels from the model of Moczydlowski and Latorre (Moczydlowski \& Latorre, 1983) and a hypothetical TRPM2-like channel using arbitrary base rate-constants, but Q10 (15.6) measured by Togashi et al., 2006 (Togashi et al., 2006). Ion channel permeabilities were from Alexander et al., 2015 (Alexander et al., 2015). (c) We replaced the former bulk $\mathrm{Ca}^{2+}$ accumulation mechanism (Feetham, Nunn, Lewis, Dart \& Barrett-Jolley, 2015) with a new reaction diffusion (RXD) model (McDougal, Hines \& Lytton, 2013b) including central $\mathrm{Ca}^{2+}$ ion buffering. All code will be made freely available on GitHub, and if possible, ModelDB.

\section{Data analysis}

All data on graphs are shown as mean \pm SEM. Simple comparisons were made using a two-tailed Student's paired t-test. Multiple comparisons were made using a repeated measures ANOVA with multiple comparisons by Tukey's post hoc test or against control levels using Dunnett's post hoc test where appropriate. A value of $P<0.05$ was taken as significant.

\section{Materials}

GSK2193874 (80 $\mathrm{nM})$, gadolinium (100? $\mu \mathrm{M})$ and Econozole (10? $\mu \mathrm{M})$ were sourced from Sigma-Aldrich and were all dissolved in DMSO and diluted to a final working concentration of no more than $0.01 \%$ DMSO (0.01\% DMSO had no effect alone). 


\section{Results}

\section{Gene expression levels of thermosensitive TRP channels in punches of mouse PVN}

We measured mRNA (by quantitative qPCR) of the warm activated Tprv1 (DCt 11.50 \pm 2.97 , $\mathrm{n}=3$ ), Tprv2 (DCt 5.29 $\pm 0.32, \mathrm{n}=3$ ), Tprv3 (DCt 9.39 $\pm 0.35, \mathrm{n}=3$ ), Tprv4 (DCt 4.46 $\pm 0.22, n=3$ ) and Trpm2 (DCt 4.04 $\pm 0.36, n=3$ ) channels and mRNA levels of the cold activated Trpm8 (DCt 8.78 $\pm 1.50, n=3$ ) and Trpa1 (DCt 8.48 $2.34, n=3$ ) channels (Klein, Trannyguen, Joe, lodi \& Carstens, 2015; Nazıroğlu \& Braidy, 2017). Note lower DCt means higher mRNA abundance. Therefore, in young mice (the age used in the rest of this work) Trpv4 and Trpm2 were the most abundantly expressed of these thermosensitive TRP channels (Fig. 1). Full datasets for a set of 84 ion channel genes including these, in both young and old mice are included in the supplementary information.

\section{Identification of Trpv4 channels on PVN neurones}

To identify and characterise the single-channel gating of PVN Trpv4 channels, we used cell attached electrophysiology on PVN neurones. A Trpv4-like channel was identified in $56 \%$ of recordings with a conductance of $59.7 \pm 1 \mathrm{pS}$ and Vrev of $-5.9 \pm 3 \mathrm{mV}$ (Fig. $2 \mathrm{~A}(\mathrm{i}), \mathrm{n}=10$ ). This channel was absent when cells were patched in the presence of the specific Trpv4 antagonist GSK2193874 ( 80 nM, Fig 2B(ii)) and we have previously shown that the selective Trpv4 activator 4aPDD $(1 \mu \mathrm{M})$ significantly increased the Po of this Trpv4-like channel on PVN neurones (Feetham, Nunn, Lewis, Dart \& Barrett-Jolley, 2015).

\section{PVN Trpv4-like channels are sensitive to temperature}

Decreasing temperature dramatically reduced the $P$ o of this Trpv4-like channel $\left({ }^{*} p<0.05\right.$, $*^{* *} p<0.001$, Fig. $2 \mathrm{~A}$ and $\mathrm{B}, \mathrm{n}=9$ ). As shown in Fig. $3 \mathrm{~A}$, at $37{ }^{\circ} \mathrm{C}$, Trpv4-like channels were predominately open with only brief closing events and at lower temperatures, there was an apparent reduction in open durations. We found that the decrease in mean open probability (Po) was mediated by profound decrease in the mean open time (*** $p<0.001$, Fig. 3D, $n=9$ ) with no change in mean closed time. We also observed a small but significant decrease in Trpv4-like channel conductance when temperature was decreased (Fig. 3B, n=9, blue line).

To investigate changes in gating further, we performed detailed analysis of the open and closed dwell-time distributions. The number of time constants (tau) was 3 for both the closed and open channel levels (observed in 6/9 experiments). The remaining channels were refit to meet these tau restraints. A representative example is shown in Fig. 4. Lower temperatures markedly reduced 2 out of 3 open taus $\left(\tan _{\mathrm{O} 2}\right.$ and $\left.\tan _{\mathrm{O} 3}\right)$, with no significant 
change in any of the closed taus (Table 1). Thus, the mechanism for the temperature evoked decrease in Trpv4-like Po observed when cooled is a decrease in mean open dwell times.

\section{In silico analysis of Trpv4 inhibition and prediction of PVN action current frequency}

Characterisation of precise single ion channel gating facilitates the computation of neuronal action potential firing properties, which may correlate to how sympathetic output may be controlled. Our working hypothesis of PVN neurones is that as temperature decreases, decreasing activity of calcium permeable TRP channels leads to a decrease in the activity of nearby $\mathrm{Ca}^{2+}$-activated potassium channels $\left(\mathrm{K}_{\mathrm{Ca}}\right)$, respectively, without causing biologically significant changes in global $\left[\mathrm{Ca}^{2+}\right]$ (Feetham, Nunn, Lewis, Dart \& Barrett-Jolley, 2015). We therefore hypothesized that the reduction in Trpv4 activity observed at cooler temperatures would result in an increase in the frequency of spontaneous action currents (ACf) from PVN neurons (Fig. 5B). To test the plausibility of this hypothesis quanitatively, we constructed a mathematical model of a PVN neurone cell based on our previous model (Feetham, Nunn, Lewis, Dart \& Barrett-Jolley, 2015), as shown in Fig. 5A. Our stochastic model predicted that decreasing temperature from $37^{\circ} \mathrm{C}$ to $22^{\circ} \mathrm{C}$ would increase the frequency of spontaneous action currents (ACf) from PVN neurons $\left({ }^{*} p<0.0001, n=5\right.$, Fig. $\left.5 C\right)$.

\section{PVN neuronal action current frequency is increased at low temperatures.}

To validate our mathematical model, we used cell-attached patch-clamp electrophysiology on PVN neurones. We found that ACf was significantly higher at lower temperatures $\left(*^{* *} p<0.001\right.$, Fig. $\left.6, \mathrm{n}=7\right)$. The maximum effect was observed at room temperature $\left(22^{\circ} \mathrm{C}\right)$ where there was a 10 -fold increase in $\operatorname{ACf}(* * * p<0.001$, Fig. $6 \mathrm{~F}, \mathrm{n}=7)$.

\section{Temperature sensitivity of PVN neurons}

At lower recording temperatures, we observed an increase in ACf which is likely mediated by a decrease in $\mathrm{K}_{\mathrm{Ca}}$ activity. In this temperature range, a decrease in activity of any of our identified warm-activated $\mathrm{Ca}^{2+}$-permeable TRP channels (Trpv4, Trpv3 and Trpm2) could account for this phenomenon (see Fig 1B). We therefore repeated our temperature protocol in the presence of gadolinium (100 $\mathrm{MM}$ ) which inhibits both Trpv4 (Liedtke et al., 2000) and Trpv3 (Tousova, Vyklicky, Susankova, Benedikt \& Vlachova, 2005) and found that while the temperature response persisted from $37^{\circ} \mathrm{C}$ to $27^{\circ} \mathrm{C}\left({ }^{* *} p<0.01\right.$, Fig. $\left.7 \mathrm{C}, \mathrm{n}=6\right)$ it did not increase further as the temperature was lowered to $22^{\circ} \mathrm{C}$. It is worth nothing that at $27^{\circ} \mathrm{C}$ (the temperature threshold for Trpv4 activation), is where we observed the largest increase in ACf compared to control (**p<0.01, Fig 6C, $\mathrm{n}=6$ ).

We also repeated our temperature protocol in the presence of econazole (10 $\mu \mathrm{M})$ which is known to block the thermosensitive Trpm2 channel (Hill, McNulty \& Randall, 2004). We found that ACf no longer changed with recording temperature, indicating that the temperature response was inhibited, (Fig. $7 B, n=5$ ). However, at the higher temperatures of 
$37{ }^{\circ} \mathrm{C}$ and $32{ }^{\circ} \mathrm{C}$, ACf was markedly higher to that recorded in control conditions (no drug) $(* * p<0.01$, Fig $7 C, n=5)$.

\section{Discussion}

In this study, we identify thermosensitive TRP channels in the PVN using RT-PCR, of which, Trpv4 is the most abundantly expressed. We characterise the single-channel properties of pharmacologically identified Trpv4-like channels on PVN neurones. We report that these channels are thermosensitive, with decreased activity at lower temperatures, and although our mathematical model predicts that our single channel results could account for the increase in neuronal PVN activity we observed at lower temperatures, we find that the temperature sensitivity of PVN neurones is complex and is likely mediated by the cooperated orchestration of multiple thermosensitive channels, including Trpv4 and Trpm2.

Our results demonstrate that Trpv4-like channels are present on PVN neurones; we have previously illustrated the expression profile of Trpv4 within the PVN using immunohistochemistry (Feetham, Nunn, Lewis, Dart \& Barrett-Jolley, 2015) and have shown that application of the selective Trpv4 agonist GSK1016790A decreased the firing rate of PVN neurones (Feetham, Nunn, Lewis, Dart \& Barrett-Jolley, 2015) and at the level of the whole animal, we have shown that ICV injection of the Trpv4 inhibitor RN1734 prevents the effect of hypotonic ASCF on blood pressure (Feetham, Nunn \& Barrett-Jolley, 2015). Here, we characterise the biophysical properties of Trpv4-like channels from PVN neurones using patch-clamp electrophysiology. A Trpv4-like channel was pharmacologically identified with conductance and reversal potential similar to those reported for recombinant Trpv4 channels (Watanabe et al., 2002).

Our results are in agreement with several other studies reporting Trpv4 expression in the PVN; Carreño et al., (2009) show Trpv4-positive cells colocalised with vasopressin (AVP) in both the magnocellular and parvocellular rat PVN (Carreño, Ji \& Cunningham, 2009). However, Shenton \& Pyner (2018) reported that Trpv4-immunopositive spinally projecting (pre-autonomic) neurone cell bodies were rare in the rat PVN, with immunoreactivity predominately within the magnocellular area (Shenton \& Pyner, 2018). This is rather in contrast to our mouse data, both previously (Feetham, Nunn, Lewis, Dart \& Barrett-Jolley, 2015) and in this paper where we find Trpv4-like channel activity in $56 \%$ (9/16) of our anatomically and morphologically defined neurones in the parvocellular PVN area. That said, there are major differences between the mouse and rat PVN, for example, unlike the rat PVN, the mouse PVN is not well differentiated and magnocellular and parvocellular neurones are often indistinguishable (Biag et al., 2012). It would now be fascinating to see co-staining of Trpv4 and retrogradely labelled mouse PVN too since such data can identify 
spinally projecting (pre-autonomic) neurones directly. In addition, there have been reported mechanistic species differences too, for example, acute leptin injection induced significant PSTAT3 (a marker of leptin-responsive cells) expression in the rat PVN but not in the mouse. They also reported that the rat PVN exhibited a denser proopiomelanocortin (POMC) innervation compared to the mouse (Campos et al.). In addition, major differences in neuronal populations in different areas of the brain have been reported between species, for example, numerous CRF-ir neurones in the medial preoptic area of rats were barely observed in mice and numerous CRF-ir neurones in the dorsal nucleus of vagus nerve (DMN) of mice that were not present in rats (Wang, Goebel-Stengel, Stengel, Wu, Ohning \& Taché, 2011). In addition, Trpv4 channels have been shown to translocate; Baratchi et al., (2016) showed that in human umbilical vein endothelial cells (HUVECS) and in human embryonic kidney 293 cells (HEK293) transfected with Trpv4, sheer stress triggered translocation of Trpv4 to the plasma membrane within seconds of treatment (Baratchi, Almazi, Darby, Tovar-Lopez, Mitchell \& Mclntyre, 2016). Again in a later publication, they demonstrated that in HUVECs, upon application of shear stress, clusters of Trpv4 channels dispersed into individual channels and translocated from the basolateral to the basal membrane (Baratchi, Knoerzer, Khoshmanesh, Mitchell \& Mclntyre, 2017). It is therefore plausible that any shear stress or mechanical perturbation may cause additional Trpv4 channels to be translocated to the plasma membrane and be observed more easily at the single channel level.

We find that the gating of Trpv4-like channels is profoundly affected by temperature; Po decreased when the temperature was lowered, mediated by a decrease in mean open durations. Trpv4-like channels on PVN neurones were almost maximally activated at normal physiological body temperature, which has been reported elsewhere for TRPV4 channels expressed in HEK293 cells (Watanabe, Vriens, Suh, Benham, Droogmans \& Nilius, 2002) and for TRPV4 in isolated hippocampal pyramidal neurons (Shibasaki, Suzuki, Mizuno \& Tominaga, 2007). The general consensus is that at physiological temperatures, TRPV4 channels may serve as constitutively open $\mathrm{Ca}^{2+}$ entry channels that are sensitive to small deviations in temperature (Watanabe, Vriens, Suh, Benham, Droogmans \& Nilius, 2002) and control neuronal excitability in vitro and in vivo (Shibasaki et al., 2015; Shibasaki, Suzuki, Mizuno \& Tominaga, 2007).

Although the molecular dynamics behind heat activation of Trpv4-like channels in the PVN is not known, Watanabe et al., (2002) illustrated that whilst 4aPDD can activate TRPV4 channels in both the cell-attached and cell-free patch clamp configurations, heat application could only activate channels in the cell-attached mode, suggesting that there might be an intrinsic heat sensitive ligand or messenger that can active TRPV4 channels from the inside rather than heat activating the channel directly (Watanabe, Vriens, Suh, Benham, Droogmans \& Nilius, 2002). We do not know the mechanism behind the heat activation of Trpv4 channels on PVN neurones as we only patched in the cell-attached mode but we could hypothesise that there may be a similar mechanism here. 
We have previously shown that pharmacological activation of Trpv4 decreases spontaneous ACf of PVN neurones, mediated by the $\mathrm{Ca}^{2+}$-induced activation of $\mathrm{K}_{\mathrm{Ca}}$ channels (Feetham, Nunn, Lewis, Dart \& Barrett-Jolley, 2015). Activation of $\mathrm{K}_{\mathrm{Ca}}$ channels induces hyperpolarisation, which in turn, draws greater $\mathrm{Ca}^{2+}$ into the cell by increasing the driving force for $\mathrm{Ca}^{2+}$ entry, setting up a positive feedback loop (Feetham, Nunn, Lewis, Dart \& Barrett-Jolley, 2015; Guéguinou, Chantôme, Fromont, Bougnoux, Vandier \& PotierCartereau, 2014). In our paper and in others, our mathematical model showed that even in the absence of large global changes in $\mathrm{Ca}^{2+}$, Trpv4 could permit entry of sufficient $\mathrm{Ca}^{2+}$ to activate local SK channels, due to a combinational of local $\mathrm{Ca}^{2+}$ signaling domains that limit the diffusion of $\mathrm{Ca}^{2+}$ ions after they have entered the cell and the close proximity that often exists between the $\mathrm{Ca}^{2+}$ permeable channel (Trpv4 channel) and the $\mathrm{Ca}^{2+}$ signaling system ( $K_{\text {Ca }}$ channel) (Augustine, Santamaria \& Tanaka, 2003; Fakler \& Adelman, 2008; Neher, 1998)

We have made fundamental changes to our mathematical model. Firstly, we added probabilistic or stochastic gating of ion channels (gating between open and closed states) which attributes to 'channel noise' in neuronal activity (Goldwyn \& Shea-Brown, 2011; White, Rubinstein \& Kay, 2000). It has been demonstrated that the Hodgkin-Huxley derived neuronal models with discrete Markovian ion channel kinetics instead of the usual rate equations can lead to spontaneous generation of action potentials (Hänggi, 2002; Lecar \& Nossal, 1971; Skaugen \& Walløe, 1979; Strassberg \& DeFelice, 1993). In addition, including stochastic behaviour of ion channel gating imparts neuronal noise (Cannon, O'Donnell \& Nolan, 2010) that has been shown to effect the variability of spike timing (Schneidman, Freedman \& Segev, 1998), firing coherence (Sun, Lei, Perc, Lu \& Lv, 2011) and the regularity of spontaneous spike activity (Ozer, Perc \& Uzuntarla, 2009). We therefore employed stochastic channels where possible, using the established architecture in NEURON (Hines \& Carnevale, 1997b). Also, in the previous model we used intracellular $\mathrm{Ca}^{2+}$ buffering that was available in NEURON (Hines \& Carnevale, 1997b) but here, we updated to the newer reaction diffusion (RXD) meshwork within pyNeuron (McDougal, Hines \& Lytton, 2013a; Newton, McDougal, Hines \& Lytton, 2018). This allowed us to model very local changes of $\mathrm{Ca}^{2+}$ ions in the direct region of the TRP channel-Ca ${ }^{2+}$-activated potassium channel microdomain. This microdomain approach is critical for understanding functional couplings. Clearly $\mathrm{Ca}^{2+}$ concentration does not need to increase across the entire body of the cell, and indeed this is an observation that has been verified in other cell types (Fakler \& Adelman, 2008) .

Our mathematic simulations predicted that the reduction in Trpv4 Po observed at lower temperatures would decrease ACf if the same Trpv4/SK mechanism was at play. In our electrophysiology experiments on neurons in the parvocellular PVN area, we observed a decrease in ACf as we cooled from physiological $\left(37^{\circ} \mathrm{C}\right)$ to room $\left(22^{\circ} \mathrm{C}\right)$ temperature (Fig. 6$)$. At $37^{\circ} \mathrm{C}$, these neurones have little spontaneous activity Fig. $6 \mathrm{C}$ ), which increased 1.8 fold even with a small $5^{\circ} \mathrm{C}$ decrease in temperature. Our previous work (Feetham, Nunn, Lewis, Dart \& Barrett-Jolley, 2015) was performed at room temperature and therefore in this 
study, we decreased the temperature of our bath down all the way to $22^{\circ} \mathrm{C}$ for comparative reasons.

In the presence of gadolinium, which was used to block the warm activated $\mathrm{Ca}^{2+}$-permeable TrpvV4 (Liedtke et al., 2000), TRPV3 (Tousova, Vyklicky, Susankova, Benedikt \& Vlachova, 2005) and TRPM3 (Kraft et al., 2004) channels, we found that the overall temperature response was largely still present; we observed a decrease in ACf with lower temperatures, however, the effect plateaued after $27^{\circ} \mathrm{C}$ and we did not see a further decrease when temperature was lowered further to $22^{\circ} \mathrm{C}$. We hypothesize that gadolinium is targeting Trpv4 in these experiments; at temperatures of $22^{\circ} \mathrm{C}, 27^{\circ} \mathrm{C}$ and $32^{\circ} \mathrm{C}$, in the presence of gadolinium we see an increase in ACf compared to control, which fits our Trpv4/SK functional coupling model of PVN neurones where a reduction in Trpv4 Po would lead to an increase in ACf. Surprisingly, at $37^{\circ} \mathrm{C}$, where we know Trpv4 Po would be very high, we did not see any increase in ACf when Trpv4 was inhibited, indicating that another ion channel may be involved.

The remaining target, Trpm 2 has been identified as a heat sensor in the POA (Song et al., 2016), is gadolinium insensitive (Harteneck, 2005) and is activated by temperatures $>35{ }^{\circ} \mathrm{C}$ (Togashi et al., 2006). We therefore repeated our temperature procedure in the presence of $10 \mu \mathrm{M}$ econazole which is known to inhibit Trpm2 currents (Hill, McNulty \& Randall, 2004) and found that the temperature effect on ACf at all temperatures was blocked, indicating a role for Trpm2 in thermosensing in the PVN. In the presence of econazole, compared to control recordings (no drug), we found that ACf was increased at all temperatures apart from room temperature $\left(22^{\circ} \mathrm{C}\right)$ and the effect was most pronounced at $37^{\circ} \mathrm{C}$ which is just above is the temperature activation threshold of Trpm 2 .

Interestingly, Song et al., (2016) suggested that Trpm2 in preoptic hypothalamic neurones modulates fever responses via the PVN (Song et al., 2016). They found that inhibition of $\mathrm{TRPM}^{+} \mathrm{POA}$ neurones resulted in a significant increase in $\mathrm{T}_{\mathrm{c}}$. This may fit in with our results; we did not patch isolated PVN neurones, but PVN neurones in their somewhat native neuronal environment and thus, any interference from neighboring hypothalamic nuclei such as the POA may be preserved in our brain slice experiments. We show that at $37^{\circ} \mathrm{C}$, inhibition of Trpm2 results in a 10-fold increase in ACf, which we hypothesize would lead to an increased sympathetic output and vasoconstriction, which may result in an increase in $T_{c}$. In our single channel electrophysiology experiments, we did not observe a TRPM2-like channel, so we cannot comment on the presence of Trpm2 on PVN neurones or add to the kinetic profile of Trpm2.

We propose that both Trpv4 and Trpm2 are necessary in combination to account for our electrophysiological results; at physiological temperatures we know Trpv4 activity will be high (Fig. 3A) and we assume that Trpm2 will be active as we are over the temperature activation threshold. Inhibiting Trpv4 (with gadolinium) had no effect on ACf, presumably because TRPM 2 is still active and conducting enough $\mathrm{Ca}^{2+}$ to maintain SK channel activity. 
This may be surprising considering Trpv4 has a permeability ratio $\mathrm{Ca}^{2+}$ to $\mathrm{Na}^{+}$(PCa/Pna) of 6 (Clapham, Montell, Schultz \& Julius, 2003), whereas Trpm2 PCa/PNa is approximately only 0.7 (Kraft et al., 2004; Sano et al., 2001) but we know from our mathematical model that only a small about of $\mathrm{Ca}^{2+}$ entry is required to activate nearby $\mathrm{K}_{\mathrm{Ca}}$ channels. Further work is necessary to confirm the presence of TRPM2 (as opposed to a closely related channel) in the PVN and to determine the comparative expression profile of Trpv4 and Trpv2. As we cool to room temperature, we presume TRPM2 be switched off first (sub $35^{\circ} \mathrm{C}$ ) whereas Trpv4 will be constitutively active even at room temperature, albeit with low Po (Fig. 3A). Inhibiting Trpm2 at room temperature has no significant effect on ACf (presumably as Trpm2 is already switched off), whereas inhibition of Trpv4 results in a significant increase in ACf, suggesting that Trpv4 plays a role in determining neuronal activity at $22^{\circ} \mathrm{C}$. We find that blocking Trpm 2 with econozole appears to inhibit the temperature effect; ACf is markedly increased (compared to control) at $37{ }^{\circ} \mathrm{C}$ and remains consistently high as the temperature is lowered. In addition, in our mathematical model, both the presence of Trpv4 and Trpm2 were necessary to account for our physiological data, further suggesting that multiple TRP channels orchestrate the observed response.

In conclusion, our data suggest that cooling temperature challenge inhibits multiple TRP channels including Trpv4 and Trpm2. Our mathematical model predicts that resulting decreases in intracellular $\mathrm{Ca}^{2+}$ would inhibit local SK channels, depolarise neurones and hence increase ACf and our experimental patch-clamp data validates this. Together, these data give insight into the important fundamental mechanisms by which the body decodes temperature signals and maintains homeostasis in an area of the brain adapted to control of the cardiovascular control system.

Table 1. Time constants and percentage areas are shown as obtained from maximum likelihood fitting of pdfs to closed and open lifetime distributions of Trpv4-like channels from PVN neurones. Data are presented as mean \pm SEM for 7-9 experiments $\left({ }^{*} p<0.05\right.$, $* * p<0.01, * * * p<0.0001)$.

Table 2? Markov model tables?

\section{Closed}

\begin{tabular}{|c|c|c|c|c|c|}
\hline \multicolumn{2}{|c|}{$22{ }^{\circ} \mathbf{C}$} & \multicolumn{2}{c|}{$32^{\circ} \mathbf{C}$} & \multicolumn{2}{c|}{$37^{\circ} \mathbf{C}$} \\
\hline tau (ms) & Area (\%) & tau (ms) & Area (\%) & tau (ms) & Area (\%) \\
\hline $0.58 \pm 0.01$ & 58 & $0.75 \pm 0.02$ & 65 & $1.24 \pm 0.3$ & 69 \\
\hline $5.26 \pm 0.02$ & 30 & $5.87 \pm 0.2$ & 27 & $7.28 \pm 2.3$ & 24 \\
\hline
\end{tabular}


$71.22 \pm 3.9$
12

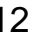

$49.96 \pm 6.9$
7

$82.19 \pm$
7

\begin{tabular}{|c|c|c|c|c|c|}
\hline \multicolumn{6}{|l|}{ Open } \\
\hline \multicolumn{2}{|c|}{$22^{\circ} \mathrm{C}$} & \multicolumn{2}{|c|}{$32^{\circ} \mathrm{C}$} & \multicolumn{2}{|c|}{$37^{\circ} \mathrm{C}$} \\
\hline tau (ms) & Area (\%) & tau (ms) & Area (\%) & tau (ms) & Area (\%) \\
\hline $1.32 \pm 0.68$ & 40 & $1.88 \pm 0.41$ & 38 & $2.73 \pm 0.32$ & 28 \\
\hline $3.99 \pm 1.65$ & 39 & $14.14 \pm 2.3^{* *}$ & 39 & $40.07 \pm 8.22^{* * *}$ & 49 \\
\hline $41.51 \pm 12.06$ & 21 & $106.55 \pm 19.36^{*}$ & 23 & $224.57 \pm 48.17^{* *}$ & 23 \\
\hline
\end{tabular}

\section{References}

Alawi KM, Aubdool AA, Liang L, Wilde E, Vepa A, Psefteli MP, et al. (2015). The sympathetic nervous system is controlled by transient receptor potential vanilloid 1 in the regulation of body temperature. Faseb j 29: 4285-4298.

Alexander SP, Kelly E, Marrion N, Peters JA, Benson HE, Faccenda E, et al. (2015). The Concise Guide to PHARMACOLOGY 2015/16: Overview. Br J Pharmacol 172: 5729-5743.

Amir S (1990). Stimulation of the paraventricular nucleus with glutamate activates interscapular brown adipose tissue thermogenesis in rats. Brain research 508: 152-155.

Augustine GJ, Santamaria F, \& Tanaka K (2003). Local Calcium Signaling in Neurons. Neuron 40: 331-346.

Bachtell RK, Tsivkovskaia NO, \& Ryabinin AE (2003). Identification of temperature-sensitive neural circuits in mice using c-Fos expression mapping. Brain research 960: 157-164.

Baldino F, Jr., \& Geller HM (1982). Electrophysiological analysis of neuronal thermosensitivity in rat preoptic and hypothalamic tissue cultures. The Journal of physiology 327: $173-184$.

Baratchi S, Almazi JG, Darby W, Tovar-Lopez FJ, Mitchell A, \& Mclntyre P (2016). Shear stress mediates exocytosis of functional TRPV4 channels in endothelial cells. Cellular and Molecular Life Sciences 73: 649-666. 
Baratchi S, Knoerzer M, Khoshmanesh K, Mitchell A, \& Mclntyre P (2017). Shear Stress Regulates TRPV4 Channel Clustering and Translocation from Adherens Junctions to the Basal Membrane. Scientific Reports 7: 15942.

Barrett-Jolley R, Pyner S, \& Coote JH (2000). Measurement of voltage-gated potassium currents in identified spinally-projecting sympathetic neurones of the paraventricular nucleus. Journal of Neuroscience Methods 102: 25-33.

Barry PH, \& Lynch JW (1991). Liquid junction potentials and small cell effects in patch-clamp analysis. The Journal of membrane biology 121: 101-117.

Belle MD, Diekman CO, Forger DB, \& Piggins HD (2009). Daily electrical silencing in the mammalian circadian clock. Science 326: 281-284.

Biag J, Huang Y, Gou L, Hintiryan H, Askarinam A, Hahn JD, et al. (2012). Cyto- and chemoarchitecture of the hypothalamic paraventricular nucleus in the $\mathrm{C} 57 \mathrm{BL} / 6 \mathrm{~J}$ male mouse: A study of immunostaining and multiple fluorescent tract tracing. Journal of Comparative Neurology 520: 6-33.

Boulant JA, \& Hardy JD (1974). The effect of spinal and skin temperatures on the firing rate and thermosensitivity of preoptic neurones. The Journal of physiology 240:639-660.

Bratincsák A, \& Palkovits M (2004). Activation of brain areas in rat following warm and cold ambient exposure. Neuroscience 127: 385-397.

BÜTtner-Ennever J (1997). The Rat Brain in Stereotaxic Coordinates, 3rd edn. J Anat 191: 315-317.

Cabral A, Valdivia S, Reynaldo M, Cyr NE, Nillni EA, \& Perello M (2012). Short-term cold exposure activates TRH neurons exclusively in the hypothalamic paraventricular nucleus and raphe pallidus. Neuroscience letters 518: 86-91.

Caldeira JC, Franci CR, \& Pelá IR (1998). Bilateral lesion of hypothalamic paraventricular nucleus abolishes fever induced by endotoxin and bradykinin in rats. Annals of the New York Academy of Sciences 856: 294-297.

Campos AMP, Teixeira PDS, Wasinski F, Klein MO, Bittencourt JC, Metzger M, et al. Differences between rats and mice in the leptin action on the paraventricular nucleus of the hypothalamus: implications for the regulation of the hypothalamic-pituitary-thyroid axis. Journal of Neuroendocrinology n/a: e12895. 
Cannon RC, O'Donnell C, \& Nolan MF (2010). Stochastic ion channel gating in dendritic neurons: morphology dependence and probabilistic synaptic activation of dendritic spikes. PLoS Comput Biol 6.

Cao WH, Fan W, \& Morrison SF (2004). Medullary pathways mediating specific sympathetic responses to activation of dorsomedial hypothalamus. Neuroscience 126: 229-240.

Carlisle HJ, \& Laudenslager ML (1979). Observations on the thermoregulatory effects of preoptic warming in rats. Physiology \& behavior 23: 723-732.

Carreño FR, Ji LL, \& Cunningham JT (2009). Altered central TRPV4 expression and lipid raft association related to inappropriate vasopressin secretion in cirrhotic rats. American journal of physiology Regulatory, integrative and comparative physiology 296: R454-466.

Cham JL, \& Badoer E (2008). Exposure to a hot environment can activate rostral ventrolateral medulla-projecting neurones in the hypothalamic paraventricular nucleus in conscious rats. Experimental Physiology 93: 64-74.

Cham JL, Klein R, Owens NC, Mathai M, McKinley M, \& Badoer E (2006). Activation of spinally projecting and nitrergic neurons in the PVN following heat exposure. American Journal of Physiology-Regulatory, Integrative and Comparative Physiology 291: R91-R101.

Chen J, Gomez-Sanchez CE, Penman A, May PJ, \& Gomez-Sanchez E (2014). Expression of mineralocorticoid and glucocorticoid receptors in preautonomic neurons of the rat paraventricular nucleus. American journal of physiology Regulatory, integrative and comparative physiology 306: R328-R340.

Clapham DE (2003). TRP channels as cellular sensors. Nature 426: 517-524.

Clapham DE, Montell C, Schultz G, \& Julius D (2003). International Union of Pharmacology. XLIII. Compendium of voltage-gated ion channels: transient receptor potential channels. Pharmacological reviews 55: 591-596.

Clark G, Magoun HW, \& Ranson SW (1939). HYPOTHALAMIC REGULATION OF BODY TEMPERATURE. Journal of Neurophysiology 2: 61-80.

de Menezes RC, Zaretsky DV, Fontes MA, \& DiMicco JA (2006). Microinjection of muscimol into caudal periaqueductal gray lowers body temperature and attenuates increases in 
temperature and activity evoked from the dorsomedial hypothalamus. Brain research 1092: 129-137.

Dimicco JA, \& Zaretsky DV (2007). The dorsomedial hypothalamus: a new player in thermoregulation. American journal of physiology Regulatory, integrative and comparative physiology 292: R47-63.

Edinger HM, \& Eisenman JS (1970). Thermosensitive neurons in tuberal and posterior hypothalamus of cats. The American journal of physiology 219: 1098-1103.

Everaerts W, Gees M, Alpizar YA, Farre R, Leten C, Apetrei A, et al. (2011). The capsaicin receptor TRPV1 is a crucial mediator of the noxious effects of mustard oil. Curr Biol 21: 316321.

Fakler B, \& Adelman JP (2008). Control of $\mathrm{K}(\mathrm{Ca})$ channels by calcium nano/microdomains. Neuron 59: 873-881.

Feetham CH, Nunn N, \& Barrett-Jolley $R$ (2015). The depressor response to intracerebroventricular hypotonic saline is sensitive to TRPV4 antagonist RN1734. Front Pharmacol 6: 83.

Feetham CH, Nunn N, Lewis R, Dart C, \& Barrett-Jolley R (2015). TRPV4 and KCa ion channels functionally couple as osmosensors in the paraventricular nucleus. British Journal of Pharmacology 172: 1753-1768.

Feetham CH, O'Brien F, \& Barrett-Jolley R (2018). Ion Channels in the Paraventricular Hypothalamic Nucleus (PVN); Emerging Diversity and Functional Roles. Frontiers in physiology 9: 760-760.

Filosa JA, Yao X, \& Rath G (2013). TRPV4 and the regulation of vascular tone. J Cardiovasc Pharmacol 61:113-119.

Fuller A, Carter RN, \& Mitchell D (1998). Brain and abdominal temperatures at fatigue in rats exercising in the heat. Journal of applied physiology (Bethesda, Md : 1985) 84: 877-883.

Gale CC, Mathews M, \& Young J (1970). Behavioral thermoregulatory responses to hypothalamic cooling and warming in baboons. Physiology \& behavior 5: 1-6.

Goldwyn JH, \& Shea-Brown E (2011). The what and where of adding channel noise to the Hodgkin-Huxley equations. PLoS Comput Biol 7: e1002247-e1002247. 
Gomez CR (2014). Chapter 62 - Disorders of body temperature. In Handbook of Clinical Neurology. eds Biller J., \& Ferro J.M. Elsevier, pp 947-957.

Guéguinou M, Chantôme A, Fromont G, Bougnoux P, Vandier C, \& Potier-Cartereau M (2014). KCa and Ca2+ channels: The complex thought. Biochimica et Biophysica Acta (BBA) Molecular Cell Research 1843: 2322-2333.

Güler AD, Lee H, lida T, Shimizu I, Tominaga M, \& Caterina M (2002). Heat-evoked activation of the ion channel, TRPV4. J Neurosci 22: 6408-6414.

H T Hammel a, \& Pierce JB (1968). Regulation of Internal Body Temperature. Annual Review of Physiology 30: 641-710.

Hammel HT, Hardy JD, \& Fusco MM (1960). Thermoregulatory responses to hypothalamic cooling in unanesthetized dogs. The American journal of physiology 198: 481-486.

Hänggi P (2002). Stochastic Resonance in Biology How Noise Can Enhance Detection of Weak Signals and Help Improve Biological Information Processing. ChemPhysChem 3: 285290.

Hardy JD (1961). Physiology of Temperature Regulation. Physiological Reviews 41: 521-606.

Hardy JD, Hellon RF, \& Sutherland K (1964). TEMPERATURE-SENSITIVE NEURONES IN THE DOG'S HYPOTHALAMUS. The Journal of physiology 175: 242-253.

Harteneck C (2005). Function and pharmacology of TRPM cation channels. NaunynSchmiedeberg's archives of pharmacology 371: 307-314.

Heeren J, \& Münzberg H (2013). Novel aspects of brown adipose tissue biology. Endocrinology and metabolism clinics of North America 42: 89-107.

Hemingway A, Forgrave P, \& Birzis L (1954). Shivering suppression by hypothalamic stimulation. J Neurophysiol 17: 375-386.

Hill K, McNulty S, \& Randall AD (2004). Inhibition of TRPM2 channels by the antifungal agents clotrimazole and econazole. Naunyn-Schmiedeberg's archives of pharmacology 370 : 227-237. 
Hines ML, \& Carnevale NT (1997a). The NEURON simulation environment. Neural Computation 9: 1179-1209.

Hines ML, \& Carnevale NT (1997b). The NEURON simulation environment. Neural Comput 9: 1179-1209.

Hines ML, Davison AP, \& Muller E (2009). NEURON and Python. Front Neuroinform 3: 1.

Hori T, Nakashima T, Hori N, \& Kiyohara T (1980). Thermo-sensitive neurons in hypothalamic tissue slices in vitro. Brain research 186: 203-207.

Horn T, Wilkinson MF, Landgraf R, \& Pittman QJ (1994). Reduced febrile responses to pyrogens after lesions of the hypothalamic paraventricular nucleus. The American journal of physiology 267: R323-328.

Inenaga K, Osaka T, \& Yamashita H (1987). Thermosensitivity of neurons in the paraventricular nucleus of the rat slice preparation. Brain research 424:126-132.

Kanosue K, Crawshaw LI, Nagashima K, \& Yoda T (2010). Concepts to utilize in describing thermoregulation and neurophysiological evidence for how the system works. Eur J Appl Physiol 109: 5-11.

Kanosue K, Niwa K, Andrew PD, Yasuda H, Yanase M, Tanaka H, et al. (1991). Lateral distribution of hypothalamic signals controlling thermoregulatory vasomotor activity and shivering in rats. The American journal of physiology 260: R486-493.

Kanosue K, Yanase-Fujiwara M, \& Hosono T (1994). Hypothalamic network for thermoregulatory vasomotor control. The American journal of physiology 267: R283-288.

Kazuyuki K, Hosono T, Zhang YH, \& Chen XM (1998). Neuronal networks controlling thermoregulatory effectors. Progress in brain research 115: 49-62.

Kiss JZ, Martos J, \& Palkovits M (1991). Hypothalamic paraventricular nucleus: a quantitative analysis of cytoarchitectonic subdivisions in the rat. J Comp Neurol 313: 563-573.

Klein AH, Trannyguen M, Joe CL, lodi CM, \& Carstens E (2015). Thermosensitive transient receptor potential (TRP) channel agonists and their role in mechanical, thermal and nociceptive sensations as assessed using animal models. Chemosens Percept 8: 96-108. 
Kobayashi S, \& Murakami N (1982). Thermosensitive neurons in slice preparations of rat medulla oblongata. Brain research bulletin 8: 721-726.

Koutcherov Y, Mai JK, Ashwell KW, \& Paxinos G (2000). Organization of the human paraventricular hypothalamic nucleus. J Comp Neurol 423: 299-318.

Kraft R, Grimm C, Grosse K, Hoffmann A, Sauerbruch S, Kettenmann H, et al. (2004). Hydrogen peroxide and ADP-ribose induce TRPM2-mediated calcium influx and cation currents in microglia. American journal of physiology Cell physiology 286: C129-137.

Lamas JA, Rueda-Ruzafa L, \& Herrera-Pérez S (2019). Ion Channels and Thermosensitivity: TRP, TREK, or Both? Int J Mol Sci 20.

Laursen WJ, Bagriantsev SN, \& Gracheva EO (2014). Chapter Four - TRPA1 Channels: Chemical and Temperature Sensitivity. In Current Topics in Membranes. eds Islas L.D., \& Qin F. Academic Press, pp 89-112.

Lecar H, \& Nossal R (1971). Theory of threshold fluctuations in nerves. II. Analysis of various sources of membrane noise. Biophys J 11: 1068-1084.

Leite LH, Zheng H, Coimbra CC, \& Patel KP (2012). Contribution of the paraventricular nucleus in autonomic adjustments to heat stress. Exp Biol Med (Maywood) 237: 570-577.

Lewis R, Feetham CH, Gentles L, Penny J, Tregilgas L, Tohami W, et al. (2013). Benzamil sensitive ion channels contribute to volume regulation in canine chondrocytes. Brit J Pharmacol 168: 1584-1596.

Liedtke W, Choe Y, Martí-Renom MA, Bell AM, Denis CS, Sali A, et al. (2000). Vanilloid receptor-related osmotically activated channel (VR-OAC), a candidate vertebrate osmoreceptor. Cell 103: 525-535.

Liu B, \& Qin F (2016). Use Dependence of Heat Sensitivity of Vanilloid Receptor TRPV2. Biophys J 110: 1523-1537.

Lu J, Zhang YH, Chou TC, Gaus SE, Elmquist JK, Shiromani P, et al. (2001). Contrasting effects of ibotenate lesions of the paraventricular nucleus and subparaventricular zone on sleepwake cycle and temperature regulation. J Neurosci 21: 4864-4874.

Luther JA, Daftary SS, Boudaba C, Gould GC, Halmos KC, \& Tasker JG (2002). Neurosecretory and Non-Neurosecretory Parvocellular Neurones of the Hypothalamic Paraventricular 
Nucleus Express Distinct Electrophysiological Properties. Journal of Neuroendocrinology 14: 929-932.

Magoun HW, Harrison F, Brobeck JR, \& Ranson SW (1938). ACTIVATION OF HEAT LOSS MECHANISMS BY LOCAL HEATING OF THE BRAIN. Journal of Neurophysiology 1: 101-114.

McAllen RM, Tanaka M, Ootsuka Y, \& McKinley MJ (2010). Multiple thermoregulatory effectors with independent central controls. European Journal of Applied Physiology 109: 27-33.

McDougal R, Hines M, \& Lytton W (2013a). Reaction-diffusion in the NEURON simulator. Frontiers in Neuroinformatics 7.

McDougal RA, Hines ML, \& Lytton WW (2013b). Reaction-diffusion in the NEURON simulator. Front Neuroinform 7: 28.

McKemy DD, Neuhausser WM, \& Julius D (2002). Identification of a cold receptor reveals a general role for TRP channels in thermosensation. Nature 416: 52-58.

Moczydlowski E, \& Latorre R (1983). Gating kinetics of Ca2+-activated K+ channels from rat muscle incorporated into planar lipid bilayers. Evidence for two voltage-dependent $\mathrm{Ca} 2+$ binding reactions. J Gen Physiol 82: 511-542.

Morrison SF (2016). Central control of body temperature. F1000Res 5: F1000 Faculty Rev1880.

Morrison SF, Madden CJ, \& Tupone D (2014). Central neural regulation of brown adipose tissue thermogenesis and energy expenditure. Cell metabolism 19: 741-756.

Morrison SF, \& Nakamura K (2011). Central neural pathways for thermoregulation. Front Biosci (Landmark Ed) 16: 74-104.

Nagashima K, Nakai S, Tanaka M, \& Kanosue K (2000). Neuronal circuitries involved in thermoregulation. Autonomic neuroscience : basic \& clinical 85: 18-25.

Nakamura K, \& Morrison SF (2008). A thermosensory pathway that controls body temperature. Nature neuroscience 11:62-71. 
Nakamura K, \& Morrison SF (2010). A thermosensory pathway mediating heat-defense responses. Proceedings of the National Academy of Sciences of the United States of America 107: 8848-8853.

Nakayama T, \& Hardy JD (1969). Unit responses in the rabbit's brain stem to changes in brain and cutaneous temperature. Journal of applied physiology 27: 848-857.

Nazıroğlu M, \& Braidy N (2017). Thermo-Sensitive TRP Channels: Novel Targets for Treating Chemotherapy-Induced Peripheral Pain. Front Physiol 8: 1040.

Neher E (1998). Vesicle pools and Ca2+ microdomains: new tools for understanding their roles in neurotransmitter release. Neuron 20: 389-399.

Newton AJH, McDougal RA, Hines ML, \& Lytton WW (2018). Using NEURON for ReactionDiffusion Modeling of Extracellular Dynamics. Frontiers in neuroinformatics 12: 41-41.

O'Brien F, Staunton CA, \& Barrett-Jolley R (2021). Systemic application of the TRPV4 antagonist GSK2193874 induces tail vasodilation in a mouse model of thermoregulation. bioRxiv: 2021.2003.2012.435126.

Ozer M, Perc M, \& Uzuntarla M (2009). Controlling the spontaneous spiking regularity via channel blocking on Newman-Watts networks of Hodgkin-Huxley neurons. EPL 86: 40008.

Peier AM, Reeve AJ, Andersson DA, Moqrich A, Earley TJ, Hergarden AC, et al. (2002). A heat-sensitive TRP channel expressed in keratinocytes. Science 296: 2046-2049.

Qin F (2004). Restoration of single-channel currents using the segmental k-means method based on hidden Markov modeling. Biophysical journal 86: 1488-1501.

Romanovsky AA (2007a). Thermoregulation: some concepts have changed. Functional architecture of the thermoregulatory system. American Journal of Physiology-Regulatory, Integrative and Comparative Physiology 292: R37-R46.

Romanovsky AA (2007b). Thermoregulation: some concepts have changed. Functional architecture of the thermoregulatory system. American journal of physiology Regulatory, integrative and comparative physiology 292: R37-46.

Romanovsky AA (2014). Skin temperature: its role in thermoregulation. Acta physiologica (Oxford, England) 210: 498-507. 
Sano Y, Inamura K, Miyake A, Mochizuki S, Yokoi H, Matsushime H, et al. (2001). Immunocyte Ca2+ influx system mediated by LTRPC2. Science (New York, NY) 293: 13271330.

Satinoff E (1978). Neural organization and evolution of thermal regulation in mammals. Science (New York, NY) 201: 16-22.

Schneidman E, Freedman B, \& Segev I (1998). Ion Channel Stochasticity May Be Critical in Determining the Reliability and Precision of Spike Timing. Neural Computation 10: 16791703.

Shenton FC, \& Pyner S (2018). Transient receptor potential vanilloid type 4 is expressed in vasopressinergic neurons within the magnocellular subdivision of the rat paraventricular nucleus of the hypothalamus. J Comp Neurol 526: 3035-3044.

Shibasaki K, Sugio S, Takao K, Yamanaka A, Miyakawa T, Tominaga M, et al. (2015). TRPV4 activation at the physiological temperature is a critical determinant of neuronal excitability and behavior. Pflügers Archiv - European Journal of Physiology 467: 2495-2507.

Shibasaki K, Suzuki M, Mizuno A, \& Tominaga M (2007). Effects of Body Temperature on Neural Activity in the Hippocampus: Regulation of Resting Membrane Potentials by Transient Receptor Potential Vanilloid 4. The Journal of Neuroscience 27: 1566-1575.

Sigworth FJ, \& Sine SM (1987). Data transformations for improved display and fitting of single-channel dwell time histograms. Biophys J 52: 1047-1054.

Simon E, \& Iriki M (1970). Ascending neurons of the spinal cord activated by cold. Experientia 26: 620-622.

Skaugen E, \& Walløe L (1979). Firing behaviour in a stochastic nerve membrane model based upon the Hodgkin-Huxley equations. Acta physiologica Scandinavica 107: 343-363.

Smith JE, Jansen AS, Gilbey MP, \& Loewy AD (1998). CNS cell groups projecting to sympathetic outflow of tail artery: neural circuits involved in heat loss in the rat. Brain Res 786: 153-164.

Song K, Wang H, Kamm GB, Pohle J, Reis FC, Heppenstall P, et al. (2016). The TRPM2 channel is a hypothalamic heat sensor that limits fever and can drive hypothermia. Science 353: 1393-1398. 
Sonner PM, \& Stern JE (2007). Functional role of A-type potassium currents in rat presympathetic PVN neurones. The Journal of physiology 582: 1219-1238.

Stern JE (2001). Electrophysiological and morphological properties of pre-autonomic neurones in the rat hypothalamic paraventricular nucleus. The Journal of physiology 537: 161-177.

Strassberg AF, \& DeFelice $\sqcup$ (1993). Limitations of the Hodgkin-Huxley formalism: effects of single channel kinetics on transmembrane voltage dynamics. Neural Comput 5: 843-855.

Sun XJ, Lei JZ, Perc M, Lu QS, \& Lv SJ (2011). Effects of channel noise on firing coherence of small-world Hodgkin-Huxley neuronal networks. The European Physical Journal B 79: 61-66.

Tan CL, Cooke EK, Leib DE, Lin YC, Daly GE, Zimmerman CA, et al. (2016). Warm-Sensitive Neurons that Control Body Temperature. Cell 167: 47-59.e15.

Tasker JG, \& Dudek FE (1991). Electrophysiological properties of neurones in the region of the paraventricular nucleus in slices of rat hypothalamus. The Journal of physiology 434: 271-293.

Tasker JG, \& Dudek FE (1993). Local inhibitory synaptic inputs to neurones of the paraventricular nucleus in slices of rat hypothalamus. The Journal of physiology 469: 179192.

Teague RS, \& Ranson SW (1936). THE ROLE OF THE ANTERIOR HYPOTHALAMUS IN TEMPERATURE REGULATION. American Journal of Physiology-Legacy Content 117: 562-570.

Togashi K, Hara Y, Tominaga T, Higashi T, Konishi Y, Mori Y, et al. (2006). TRPM2 activation by cyclic ADP-ribose at body temperature is involved in insulin secretion. The EMBO journal 25: 1804-1815.

Tousova K, Vyklicky L, Susankova K, Benedikt J, \& Vlachova V (2005). Gadolinium activates and sensitizes the vanilloid receptor TRPV1 through the external protonation sites. Molecular and cellular neurosciences 30: 207-217.

Walters TJ, Ryan KL, Tate LM, \& Mason PA (2000). Exercise in the heat is limited by a critical internal temperature. Journal of applied physiology (Bethesda, Md : 1985) 89: 799-806. 
Wang L, Goebel-Stengel M, Stengel A, Wu SV, Ohning G, \& Taché Y (2011). Comparison of CRF-immunoreactive neurons distribution in mouse and rat brains and selective induction of Fos in rat hypothalamic CRF neurons by abdominal surgery. Brain research 1415: 34-46.

Watanabe H, Vriens J, Suh SH, Benham CD, Droogmans G, \& Nilius B (2002). Heat-evoked activation of TRPV4 channels in a HEK293 cell expression system and in native mouse aorta endothelial cells. The Journal of biological chemistry 277: 47044-47051.

White JA, Rubinstein JT, \& Kay AR (2000). Channel noise in neurons. Trends in Neurosciences 23: 131-137.

Wünnenberg W, \& Hardy JD (1972). Response of single units of the posterior hypothalamus to thermal stimulation. Journal of applied physiology 33: 547-552.

Zaretskaia MV, Zaretsky DV, Shekhar A, \& DiMicco JA (2002). Chemical stimulation of the dorsomedial hypothalamus evokes non-shivering thermogenesis in anesthetized rats. Brain research 928: 113-125.

Zhao Z-D, Yang WZ, Gao C, Fu X, Zhang W, Zhou Q, et al. (2017). A hypothalamic circuit that controls body temperature. Proceedings of the National Academy of Sciences 114: 20422047.

\section{Figure legends}

Figure 1. Thermosensitive TRP channel gene expression in PVN punches from young mice.

A. Standardized DCt levels for seven known TRP channel mRNA in punches of the PVN (from 3 animals). Since this DCt, the green (negative values) are relatively high expression and the red (positive values) are low expression. Mean DCt was lowest (highest mRNA abundance) for TRPV4 (see values in the text). A full dataset of 84 ion channel mRNA DCt levels measured in younger (6-8 month) and older (26 month) mice are given together with heatmaps in the supplementary information. B. Established distribution of transient 
receptor potential (TRP) channels in PVN tissue as a function of their temperature threshold. TRP channels may be activated by increases in temperature (orange) or by lowering the temperature (blue) (Klein, Trannyguen, Joe, lodi \& Carstens, 2015). Image modified under BY4.0 Creative Commons licence from (Lamas, Rueda-Ruzafa \& Herrera-Pérez, 2019).

Figure 2. Single channel properties of Trpv4-like channels from PVN neurones

A. Representative single-channel current fluctuations through Trpv4-like channels from mouse PVN neurones. Holding potentials are indicated on the trace. The open and closed channel levels are indicated by $O$ and $C$, respectively. This trace is representative of 10 experiments where Trpv4-like channels were observed and these channels were absent in the presence of the TRPV4 inhibitor GSK2193874. B. The amplitude histogram is shown for the trace in A. C. Current-voltage relationship for Trpv4-like channels. Mean \pm SEM is shown $(n=9)$.

Figure 3. The gating of PVN Trpv4-like channels is temperature sensitive

A. Representative single-channel current fluctuations through Trpv4-like channels from mouse PVN neurones at $37^{\circ} \mathrm{C}, 32^{\circ} \mathrm{C}$ and $22^{\circ} \mathrm{C}$. The open and closed channel levels are indicated by $\mathrm{O}$ and $\mathrm{C}$, respectively. B. Current-voltage relationship for Trpv4-like channels at $37^{\circ} \mathrm{C}$ (red circles) and $22^{\circ} \mathrm{C}$ (blue circles). C. The Po of Trpv4-like channels at $37^{\circ} \mathrm{C}, 32^{\circ} \mathrm{C}$ and $22^{\circ} \mathrm{C}$ is shown. D. Mean open and closed times for Trpv4-like channels. Mean \pm SEM is shown ( $n=7$ at $22^{\circ} \mathrm{C}, \mathrm{n}=7$ at $32^{\circ} \mathrm{C}$ and $n=9$ at $37^{\circ} \mathrm{C}$ ). Where not shown, error bars are within the symbols.

\section{Figure 4. Kinetics of Trpv4-like channels from PVN neurones}

Kinetic analysis of Trpv4-like channel dwell-times from PVN neurones recorded in cell attached-patch mode at $37^{\circ} \mathrm{C}(\mathrm{A}), 32^{\circ} \mathrm{C}(\mathrm{B})$ and $22^{\circ} \mathrm{C}(\mathrm{C})$. Closed (left) and open (right) dwelltimes were fitted with 3 exponentials (solid lines). Data are transformed with log-binning ( $x$ axis) and square root of frequency (y-axis) so that exponential time constants are visible as peaks (Sigworth and Sine, 1987). Mean values are given in Table 1 and a kinetic schema in Fig. 5.

\section{Figure 5. In silico model of PVN neurones}

A. The simple scheme adapted from (Feetham, Nunn, Lewis, Dart \& Barrett-Jolley, 2015) whereby influx of $\mathrm{Ca}^{2+}$ increases $\mathrm{KCa}$ channel activity which hyperpolarizes the cell and increases the inward flux of $\mathrm{Ca}^{2+}$, by increasing the driving force for $\mathrm{Ca}^{2+}$ entry. B. A computer model was adapted from (Feetham, Nunn, Lewis, Dart \& Barrett-Jolley, 2015) in NEURON, which includes thermosensitive TRP channels and allows an accumulation of $\mathrm{Ca}^{2+}$ into the cell, which is linked to a KCa channel. Within the model, we can change temperature and simulate action currents, shown in C. D. Increase in action potential frequency when temperature is decreased ( $n=5$ simulation runs). 
Figure 6. Temperature decreases action current frequency of PVN neurones.

A. Representative spontaneous firing of action currents from PVN neurones are shown at physiological temperature $\left(37^{\circ} \mathrm{C}\right)$ and at lower temperatures of $32^{\circ} \mathrm{C}(\mathrm{B}), 27^{\circ} \mathrm{C}(\mathrm{C})$ and $22^{\circ} \mathrm{C}$ (D). E. Representative frequency histogram showing action current response of a PVN neurone to decreasing temperature. F. The mean temperature responses are shown for PVN neurones. Data is presented as mean $\pm \operatorname{SEM}(n=6, * * * p<0.001)$.

Figure 7. Pharmacological inhibition of various TRP channels on temperature sensitivity of PVN neurones.

Representative spontaneous firing of action currents from PVN neurones are shown at physiological temperature $\left(37^{\circ} \mathrm{C}\right)$ and at lower temperatures of $32^{\circ} \mathrm{C}, 27^{\circ} \mathrm{C}$ and $22^{\circ} \mathrm{C}$ in the presence of $(\mathbf{A})$ gadolinium or $(\mathbf{B})$ econazole. In $\mathbf{C}$., the mean temperature responses are shown for PVN neurones in the presence of gadolinium (brown) or econozol (green). Data is presented as mean \pm SEM ( $n=6$ for gadolinium, $n=5$ for econazole, $* p<0.05, * * p<0.01$ ).

\section{Supplementary figures}

Supplementary Figure 1. Ion channel gene expression in PVN punches from mice; TRP channels and calcium-activated potassium channels.

Standardized DCt levels for mRNA in punches of the PVN from 3 young (6-8 month) and 3 old (26 month) animals. (A) 12 different TRP channel genes. (B) 9 calcium-activated potassium channel related genes. The colour bar pertains to A and B. Since this DCt, the green (negative values) are relatively high expression and the red (positive values) are low expression. Raw data in Supplementary Table 1.

Supplementary Figure 2. Ion channel gene expression in PVN punches from young and old mice; inwardly rectifying potassium channels and other potassium channels.

Standardized DCt levels for mRNA in punches of the PVN from 3 young (6-8 month) and 3 old (26 month) animals. (A) Inwardly rectifying potassium channel genes. (B) Other potassium channel related genes. The colour bar pertains to A and B. Since this DCt, the green (negative values) are relatively high expression and the red (positive values) are low expression. Raw data in Supplementary Table 1.

\section{Supplementary Figure 3. Ion channel gene expression in PVN punches from young and old mice; calcium ion channels and other ion channels.}

Standardized DCt levels for mRNA in punches of the PVN from 3 young (6-8 month) and 3 old (26 month) animals. (A) Calcium voltage-gated ion channel related genes. (B) Other ion channel related genes, not included in the above families together with the transporter SIc12a5. The colour bar pertains to A and B. Since this DCt, the green (negative values) are 
relatively high expression and the red (positive values) are low expression. Raw data in Supplementary Table 1.

\section{Supplementary Table 1:}

Expression relative to mean of 3 housekeeper gene (Actb, Ldha, Rplp1) Cts for that sample is presented as the $\Delta \mathrm{Ct}$. $n=3$ for each value.

\begin{tabular}{|c|c|c|c|c|c|}
\hline \multirow{3}{*}{\multicolumn{3}{|c|}{$\begin{array}{l}\text { Expression relative to mean of } 3 \\
\text { housekeeper gene (Actb, Ldha, Rplp1) Cts } \\
\text { for that sample is presented as the } \Delta \text { Ct. } \\
n=3 \text { for each value. }\end{array}$}} & Cacnb1 & $13.44 \pm 1.13$ & $15.17 \pm 1$ \\
\hline & & & Cacnb2 & $3.57 \pm 0.84$ & $2.68 \pm 0.89$ \\
\hline & & & Cacnb3 & $8.57 \pm 0.84$ & $14.87 \pm 1.79$ \\
\hline Gene & \multicolumn{2}{|l|}{ Young ( $\Delta C t)$} & Cacng2 & $5.97 \pm 0.55$ & $4.93 \pm 0.49$ \\
\hline Asic2 & $3.27 \pm 0.21$ & $1.75 \pm 0.67$ & Cacng4 & $0.85 \pm 1.3$ & $3.6 \pm 0.8$ \\
\hline Asic1 & $5.92 \pm 1.23$ & $7.05 \pm 0.19$ & Clcn2 & $4.89 \pm 0.08$ & $3.99 \pm 0.63$ \\
\hline Asic3 & $8.46 \pm 3.36$ & $12.84 \pm 2.49$ & Clcn3 & $18.34 \pm 0.85$ & $17.13 \pm 0.35$ \\
\hline Best1 & $11.85 \pm 0.78$ & $12.61 \pm 2.19$ & Clcn7 & $4.39 \pm 0.15$ & $3.39 \pm 0.75$ \\
\hline Cacna1a & $4.46 \pm 0.65$ & $4.39 \pm 0.78$ & Hen1 & $6.96 \pm 4.22$ & $7.95 \pm 3.84$ \\
\hline Cacna1b & $-1.38 \pm 0.37$ & $2.93 \pm 2.29$ & Hon2 & $0.66 \pm 0.33$ & $-0.05 \pm 0.74$ \\
\hline Cacna1c & $4.11 \pm 0.37$ & $4.25 \pm 0.82$ & Kcna1 & $1.72 \pm 0.23$ & $1.09 \pm 0.7$ \\
\hline Cacna1d & $8.84 \pm 3.22$ & $8.5 \pm 2.41$ & Kcna2 & $2.14 \pm 0.49$ & $0.95 \pm 0.64$ \\
\hline Cacna1g & $4.66 \pm 0.04$ & $4.29 \pm 0.83$ & Kcna5 & $15.56 \pm 0.69$ & $10.24 \pm 2.51$ \\
\hline Cacna1i & $3.38 \pm 0.4$ & $3.26 \pm 0.59$ & Kcna6 & $1.98 \pm 0.56$ & $1.67 \pm 0.81$ \\
\hline
\end{tabular}




\begin{tabular}{|c|c|c|c|c|c|}
\hline Kcnab1 & $7.08 \pm 0.4$ & $5.71 \pm 0.33$ & Kcnj6 & $5.51 \pm 1.29$ & $7.3 \pm 0.23$ \\
\hline Kcnab2 & $0.6 \pm 0.26$ & $0.06 \pm 0.55$ & Kcnjg & $1.02 \pm 1.41$ & $2.86 \pm 0.82$ \\
\hline Kcnab3 & $10 \pm 4.03$ & $15.18 \pm 0.95$ & Kcnk1 & $16.08 \pm 0.6$ & $10.71 \pm 1.82$ \\
\hline Kcnb1 & $9.99 \pm 0.83$ & $8.91 \pm 1.32$ & Kcnma1 & $1.56 \pm 0.28$ & $2.19 \pm 0.52$ \\
\hline Kcnb2 & $4.53 \pm 0.08$ & $4.57 \pm 0.71$ & Kcnmb4 & $6.39 \pm 0.49$ & $7.62 \pm 0.99$ \\
\hline Kcnc1 & $3.09 \pm 0.17$ & $2.32 \pm 0.83$ & Kcnn1 & $13.67 \pm 0.72$ & $14.07 \pm 0.51$ \\
\hline Kcnc2 & $2.9 \pm 0.95$ & $1.41 \pm 1.03$ & Kcnn2 & $4.69 \pm 0.19$ & $3.6 \pm 0.83$ \\
\hline Kcnd2 & $2.44 \pm 0.11$ & $2.14 \pm 0.82$ & Kcnn3 & $9.38 \pm 1.99$ & $14.62 \pm 1.32$ \\
\hline Kcnd3 & $3.91 \pm 0.22$ & $3.09 \pm 0.8$ & Kcnq1 & $9.6 \pm 0.06$ & $9.14 \pm 0.8$ \\
\hline Kcnh1 & $4.05 \pm 0.41$ & $4.45 \pm 0.6$ & Kcnq2 & $13.77 \pm 0.48$ & $13.56 \pm 0.96$ \\
\hline Kcnh2 & $3.34 \pm 0.91$ & $3.31 \pm 0.87$ & Kcnq3 & $7.82 \pm 0.98$ & $5.4 \pm 0.73$ \\
\hline Kcnh3 & $-0.24 \pm 1.37$ & $0.7 \pm 2.93$ & Kcns1 & $10.15 \pm 1.55$ & $10.99 \pm 3.34$ \\
\hline Kcnh6 & $8.61 \pm 1.31$ & $11.29 \pm 0.49$ & Ryr3 & $5.55 \pm 0.03$ & $5.97 \pm 0.56$ \\
\hline Kcnh7 & $9.11 \pm 0.84$ & $7.3 \pm 0.46$ & Scn10a & $3.63 \pm 0.24$ & $2.85 \pm 0.61$ \\
\hline Kcnj1 & $15.88 \pm 2.16$ & $17.13 \pm 0.35$ & Scn11a & $11.84 \pm 1.18$ & $13.92 \pm 2.96$ \\
\hline Kcnj11 & $5.15 \pm 0.14$ & $4.5 \pm 0.66$ & Scn1a & $6.94 \pm 0.62$ & $5.7 \pm 0.63$ \\
\hline Kcnj12 & $3.68 \pm 0.64$ & $4.41 \pm 1.89$ & Scn1b & $-0.28 \pm 0.25$ & $-1.06 \pm 0.68$ \\
\hline Kcnj13 & $3.34 \pm 0.51$ & $7.07 \pm 1.4$ & Scn2a1 & $2.29 \pm 0.17$ & $1.62 \pm 0.64$ \\
\hline Kcnj14 & $7.33 \pm 0.09$ & $7.34 \pm 0.81$ & Scn2b & $1.39 \pm 0.12$ & $0.92 \pm 0.69$ \\
\hline Kcnj15 & $10.91 \pm 3.7$ & $17.13 \pm 0.35$ & Scn3a & $5.11 \pm 0.5$ & $4.06 \pm 0.63$ \\
\hline Kcnj16 & $13.63 \pm 1.53$ & $9.13 \pm 4.44$ & Scn8a & $1.79 \pm 0.16$ & $1.3 \pm 0.82$ \\
\hline Kcnj2 & $5.67 \pm 0.52$ & $5.32 \pm 0.64$ & Scn9a & $7.24 \pm 0.57$ & $6.68 \pm 0.59$ \\
\hline Kcnj3 & $2.64 \pm 0.19$ & $2 \pm 0.68$ & Slc12a5 & $-0.07 \pm 0.38$ & $-0.01 \pm 0.57$ \\
\hline Kcnj4 & $6.63 \pm 1.79$ & $0.62 \pm 0.85$ & Trpa1 & $8.48 \pm 2.34$ & $8.1 \pm 1.86$ \\
\hline Kcnj5 & $10.59 \pm 2.23$ & $7.13 \pm 1.99$ & Trpc1 & $4.99 \pm 0.28$ & $4.65 \pm 0.25$ \\
\hline
\end{tabular}


bioRxiv preprint doi: https://doi.org/10.1101/2022.01.26.477880; this version posted January 28, 2022. The copyright holder for this preprint (which was not certified by peer review) is the author/funder, who has granted bioRxiv a license to display the preprint in perpetuity. It is made available under aCC-BY-NC-ND 4.0 International license.

\begin{tabular}{l|ll} 
Trpc3 & $-1.53 \pm 1.88$ & $-1.85 \pm 2.09$ \\
Trpc6 & $11.2 \pm 3.55$ & $12.67 \pm 3.41$ \\
Trpm1 & $15.68 \pm 0.78$ & $17.13 \pm 0.35$ \\
Trpm2 & $4.04 \pm 0.36$ & $3.92 \pm 0.67$ \\
Trpm6 & $17.77 \pm 0.51$ & $16.87 \pm 0.36$ \\
Trpm8 & $8.78 \pm 1.5$ & $12.2 \pm 1.38$ \\
Trpv1 & $11.5 \pm 2.97$ & $15.06 \pm 0.98$ \\
Trpv2 & $5.3 \pm 0.32$ & $4.35 \pm 0.86$ \\
Trpv3 & $9.39 \pm 0.35$ & $6.49 \pm 1.64$ \\
Trpv4 & $4.56 \pm 0.21$ & $7 \pm 0.51$
\end{tabular}


bioRxiv preprint doi: https://doi.org/10.1101/2022.01.26.477880; this version posted January 28, 2022. The copyright holder for this preprint (which was not certified by peer review) is the author/funder, who has granted bioRxiv a license to display the preprint in perpetuity. It is made available under aCC-BY-NC-ND 4.0 International license. 
bioRxiv preprint doi: https://doi.org/10.1101/2022.01.26.477880; this version posted January 28, 2022. The copyright holder for this preprint (which was not certified by peer review) is the author/funder, who has granted bioRxiv a license to display the preprint in perpetuity. It is made available under aCC-BY-NC-ND 4.0 International license.

A

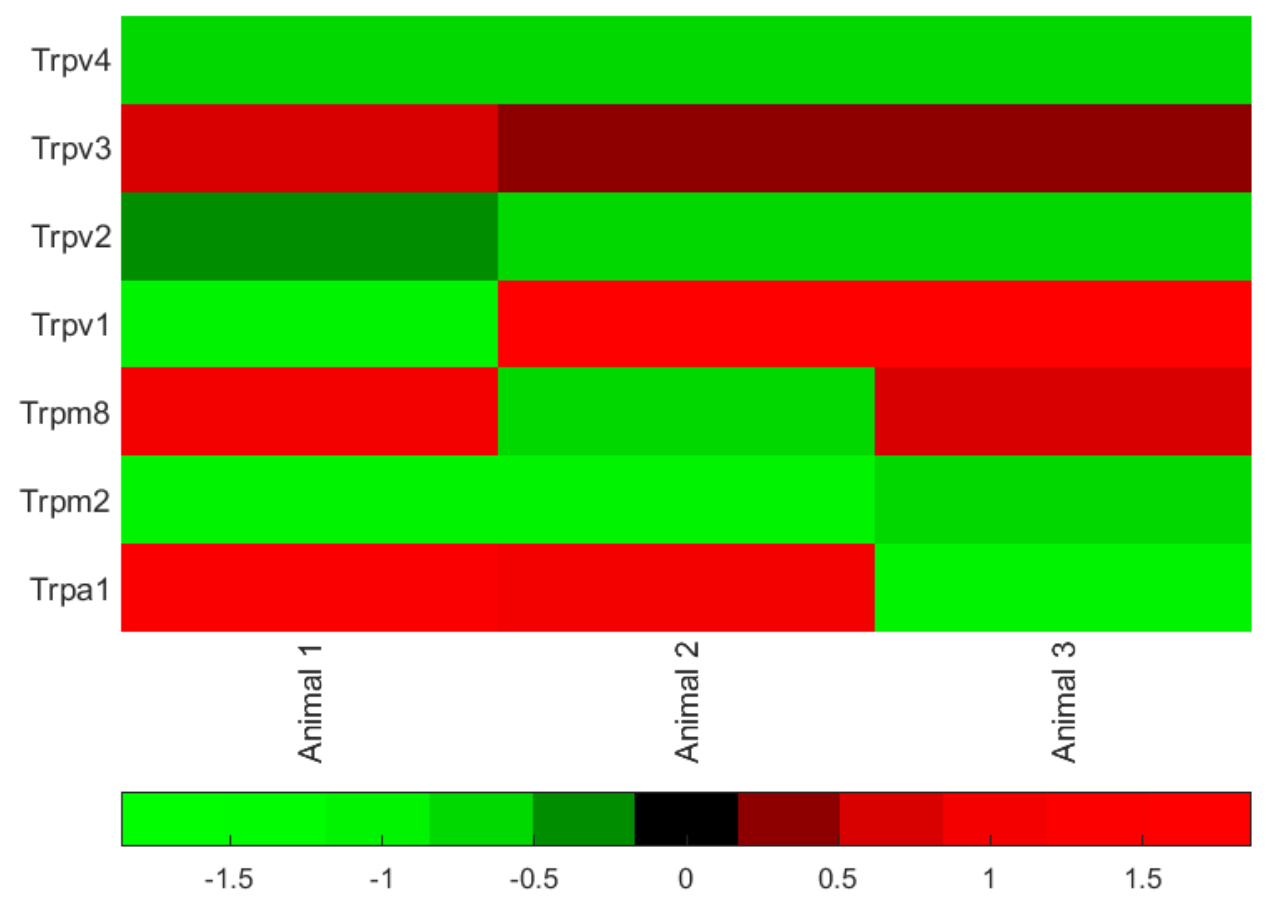

B

\section{Activated by cooling}

Activated by warming

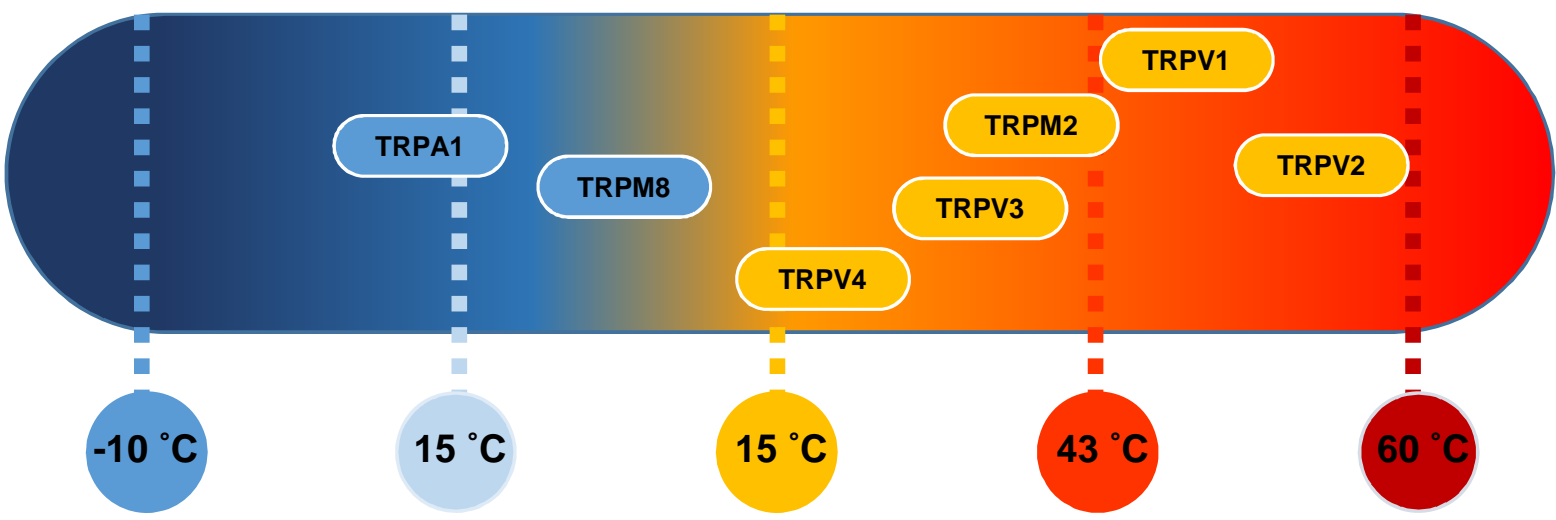

Figure 1 
(i) bioRxiv preprint doi: https://doi.org/10.1101/2022.01.26.477880; this version posted January 28,2022 . The copyright holder for this preprint A (i) (which was not certified by peer review) is the author/funder, who has granted bioRxiv a license to display the preprint in perpetyity nftis made

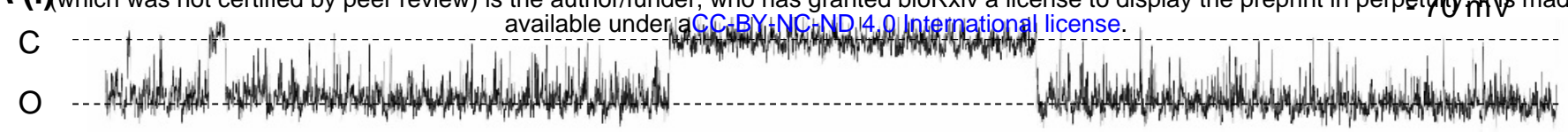
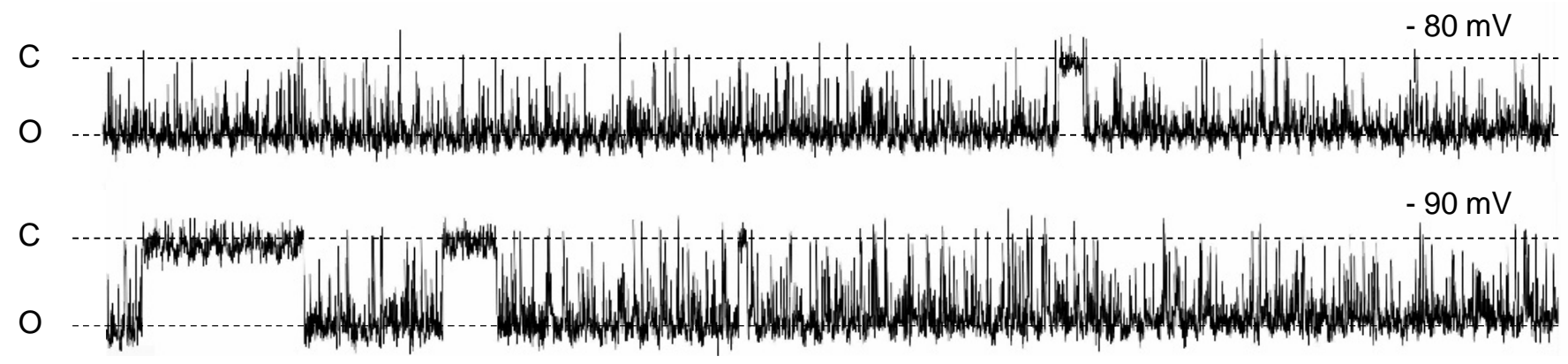

(ii)

+ GSK2193874

$-80 \mathrm{mV}$

C

$\mathrm{O}$

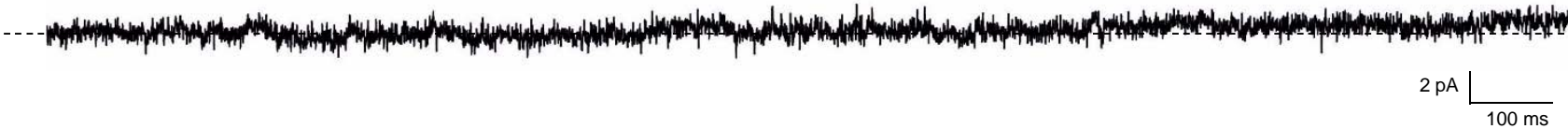

B

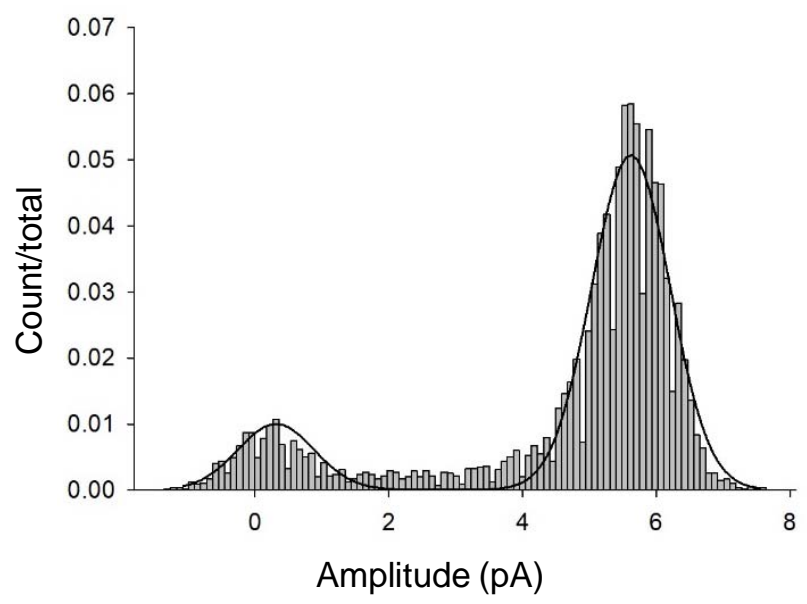

C
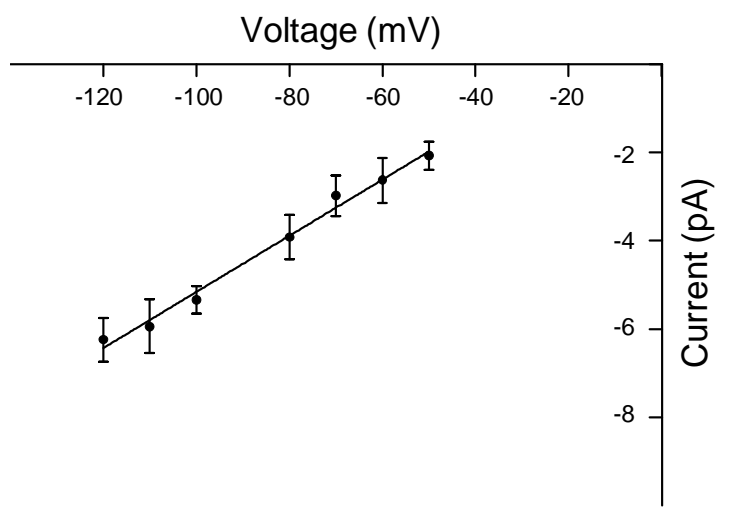

Amplitude (pA)

Figure 2 
bioRxiv preprint doi: https://doi.org/10.1101/2022.01.26.477880; this version posted Januar 28,2022 . The copyright holder for this preprint

A (which was not certified by peer review) is the author/funder, who has granted bioRxiv a lice 3 e to display the preprint in perpetuity. It is made $37^{\circ} \mathrm{C}$ available under aCC-BY-NC-ND 4.0 International license.

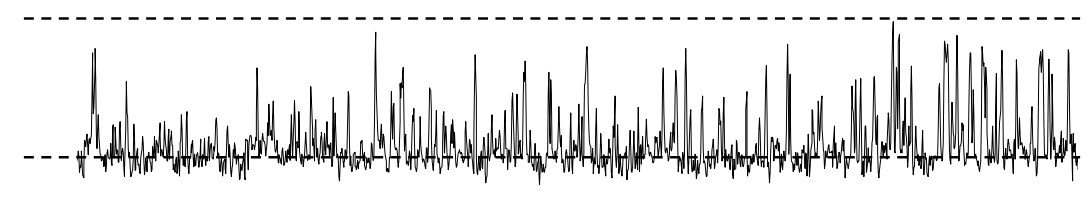

$32^{\circ} \mathrm{C}$

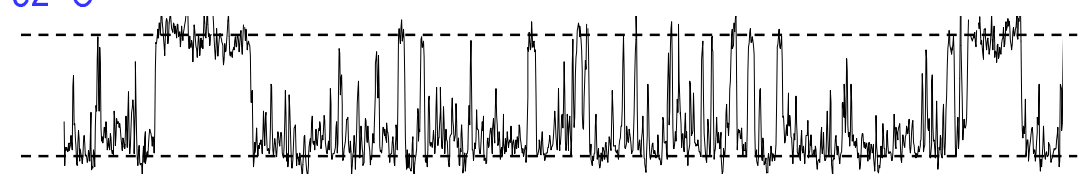

$22^{\circ} \mathrm{C}$

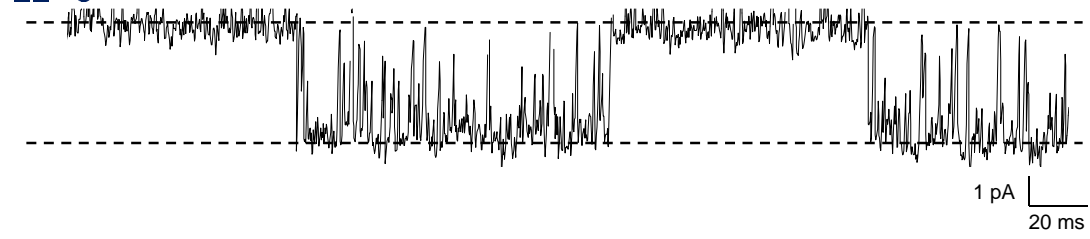

C

D (i)
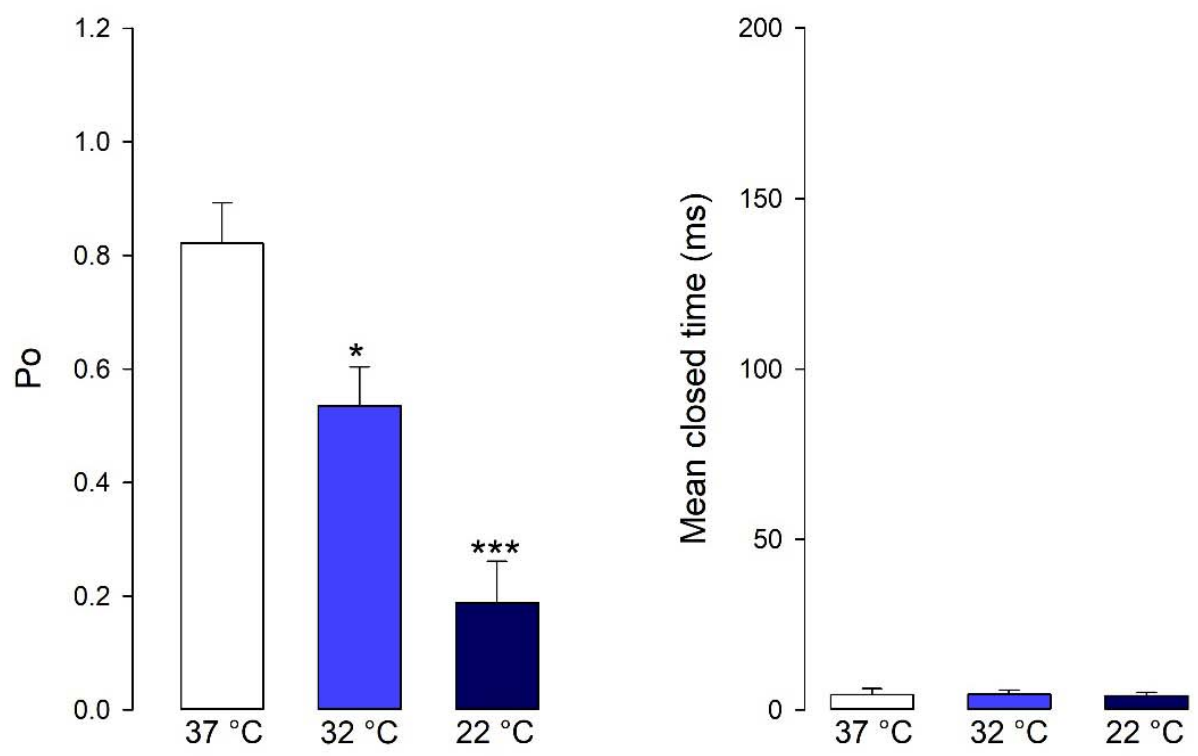

(ii)

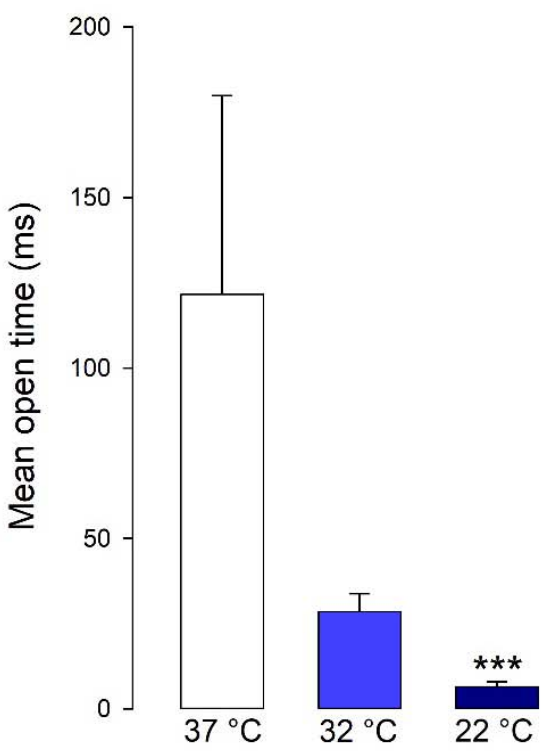

\section{Figure 3}


bioRxiv preprint doi: https://doi.org/10.1101/2022.01.26.477880; this version posted January 28,2022 . The copyright holder for this preprint

A (which was not certified by peer review) is the author/funder, who has granted bioRxiv a license to display the preprint in perpetuity. It is made

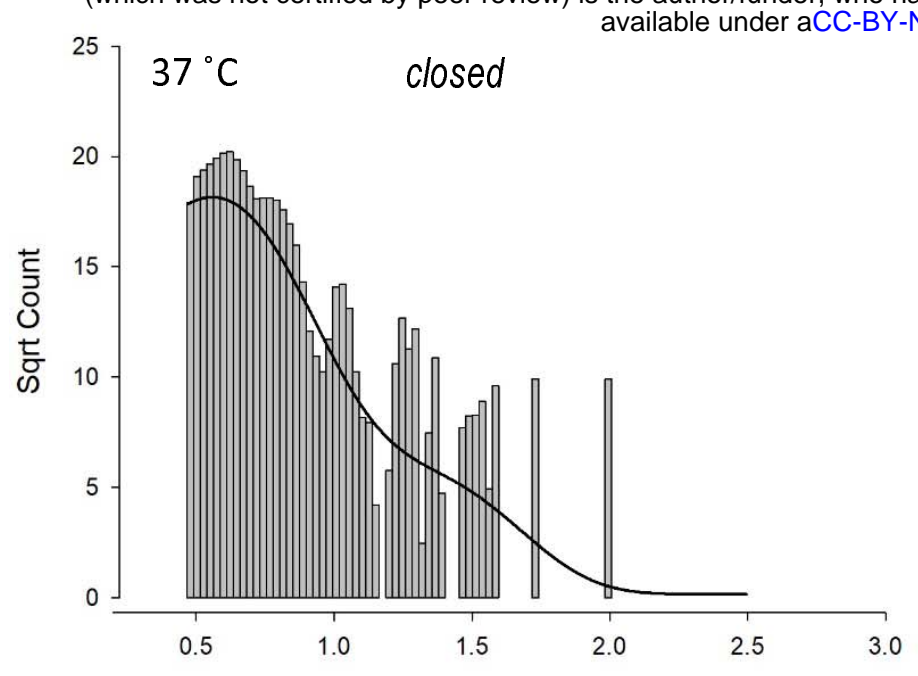

Log dwell time (ms)

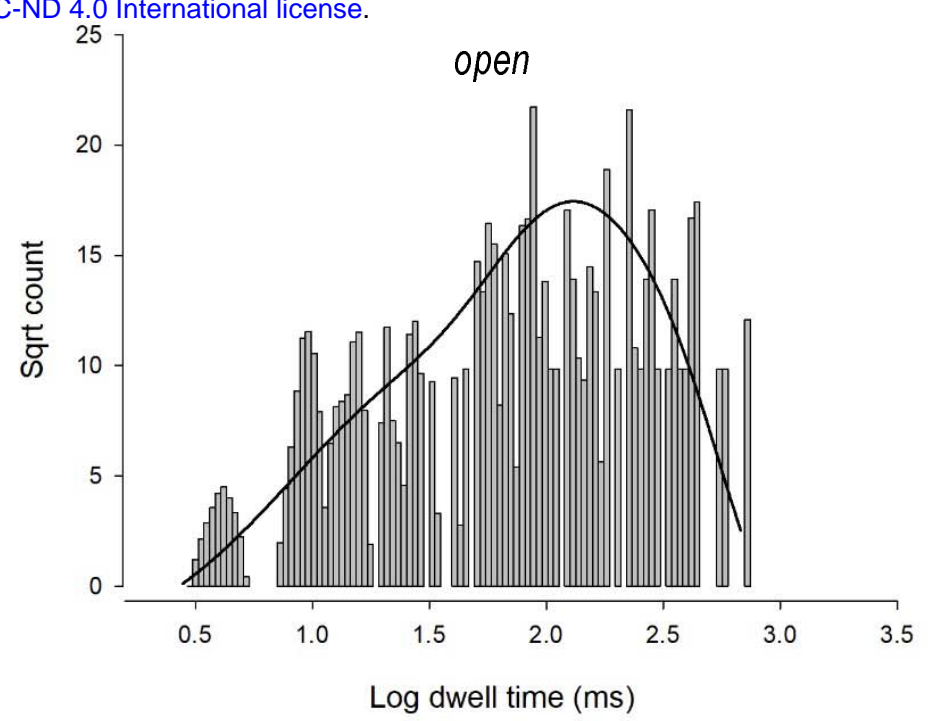

B
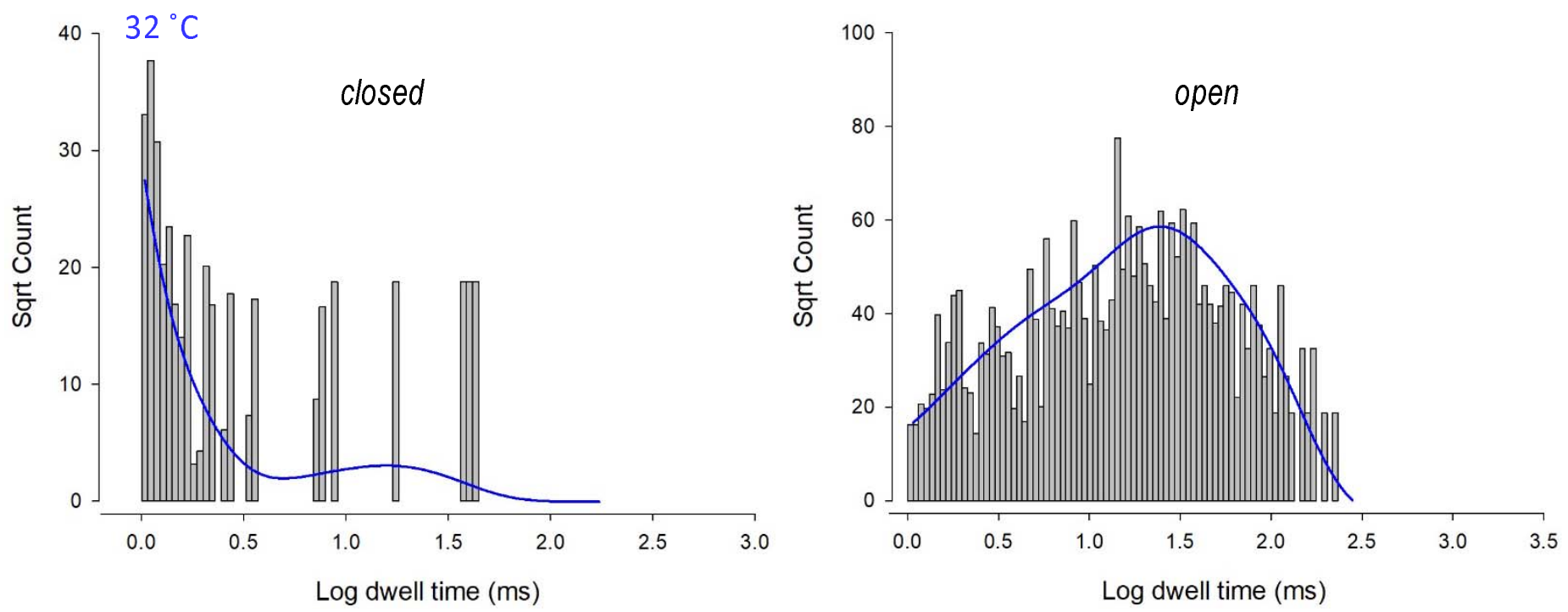

C
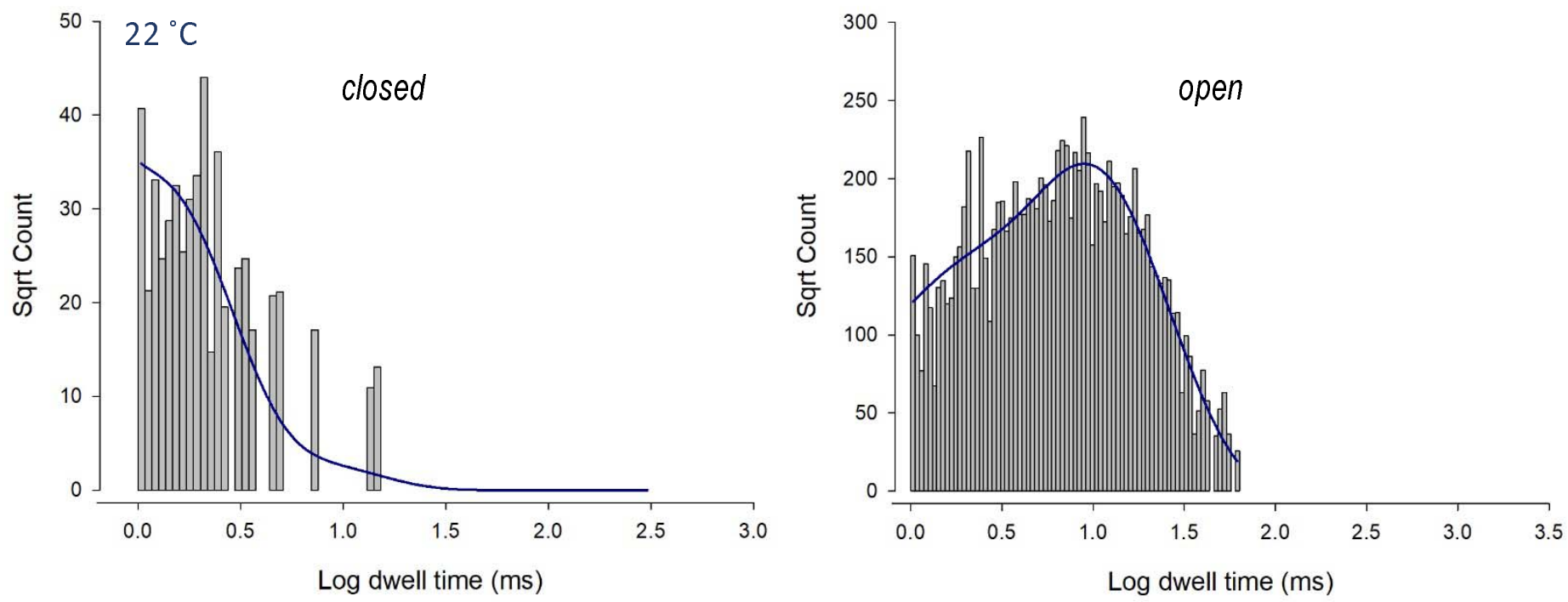

Figure 4 
bioRxiv preprint doi: https://doi.org/10.1101/2022.01.26.477880; this version posted January 28, 2022. The copyright holder for this preprint (which was not certified by peer review) is the author/funder, who has granted bioRxiv a license to display the preprint in perpetuity. It is made

$\mathbf{A}$

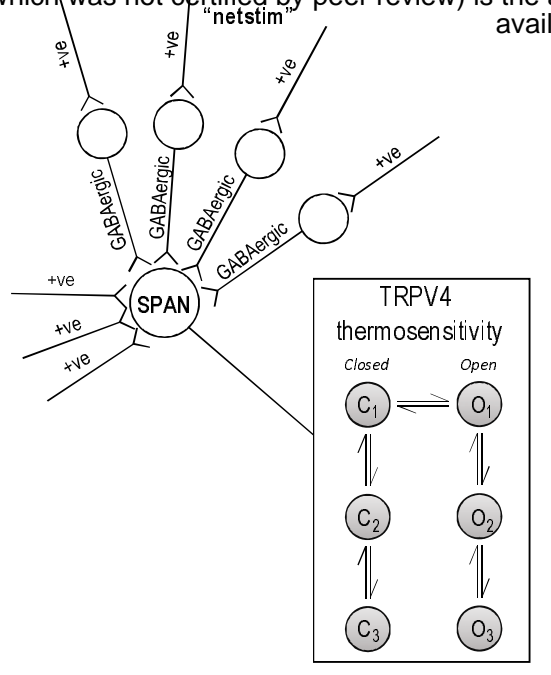
vailable under aCC-BY-NC-ND 4.0 International license.

B

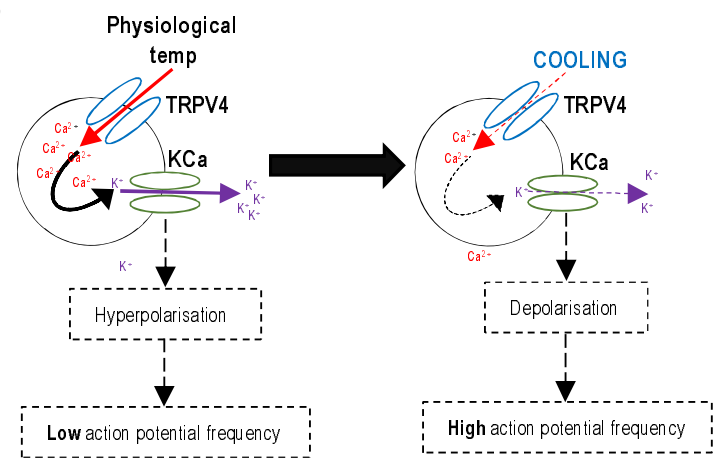

C(ii)

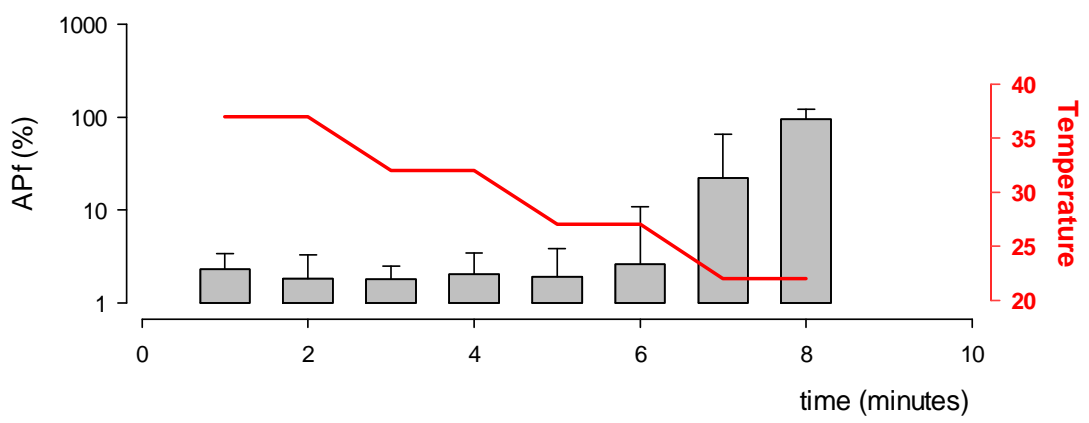

\section{Figure 5}


bioRxiv preprint doi: https://doi.org/10.1101/2022.0126.477880; this version posted January 28, 2022. The copyright holder for this preprint (which was not certified by peer review) is the author/funder, who has granted bioRxiv a license to display the preprint in perpetuity. It is made

A

$$
37^{\circ} \mathrm{C}
$$

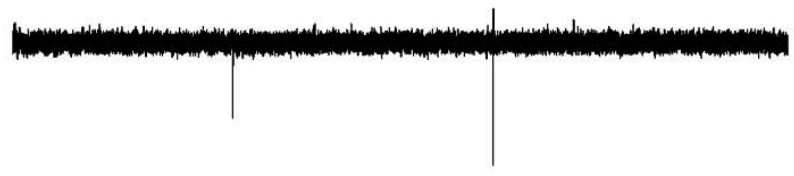

C

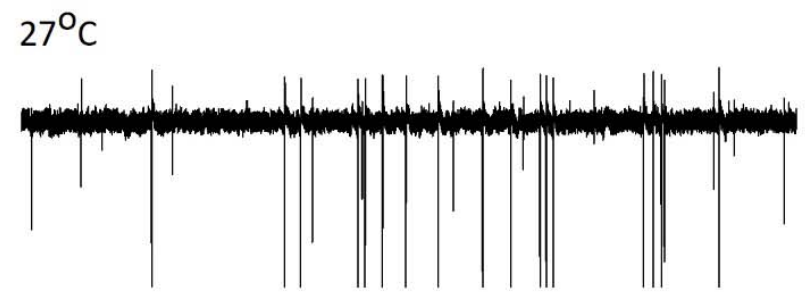

E
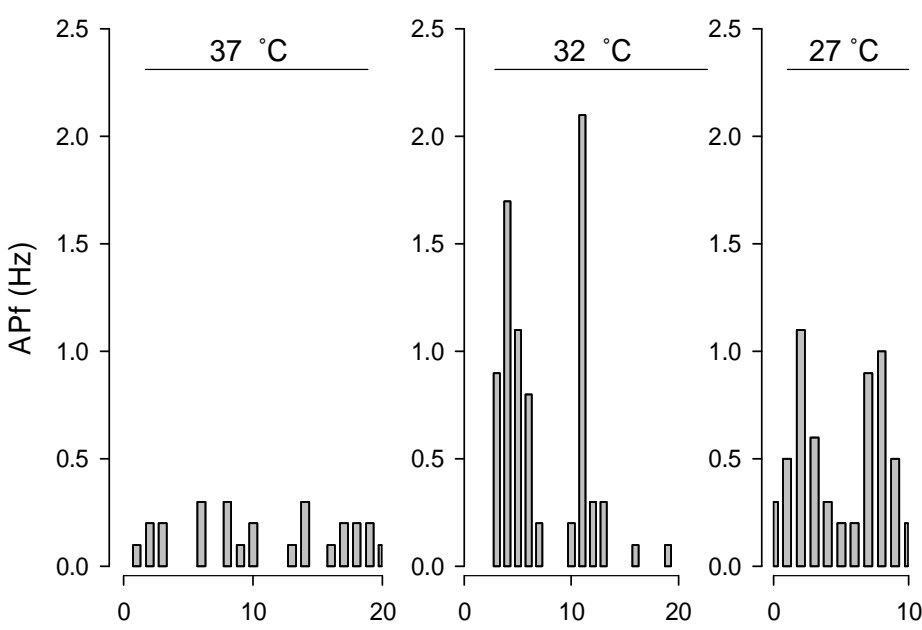

B

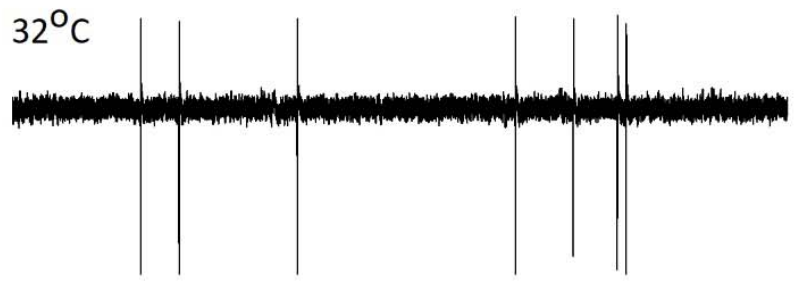

D

$22^{\circ} \mathrm{C}$

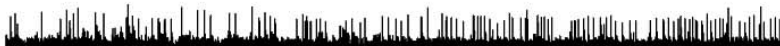

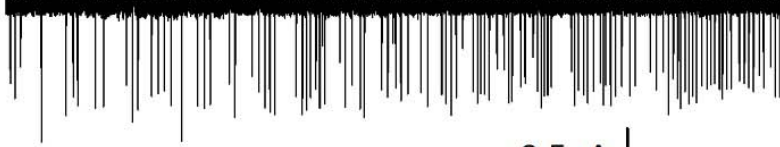

$0.5 n A$

F
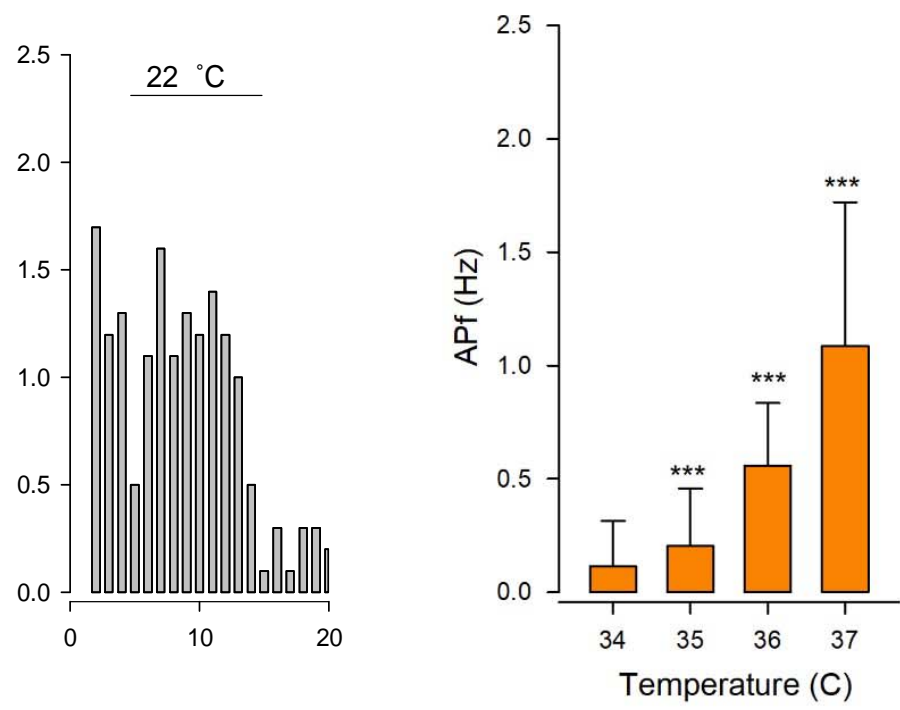

\section{Figure 6}


bioRxiv preprint doi: https://doi.org/10.1101/2022.01.26.477880; this version posted January 28, 2022. The copyright holder for this preprint (which was not certified by peer review) is the author/funder, who has granted bioRxiv a license to display the preprint in perpetuity. It is made
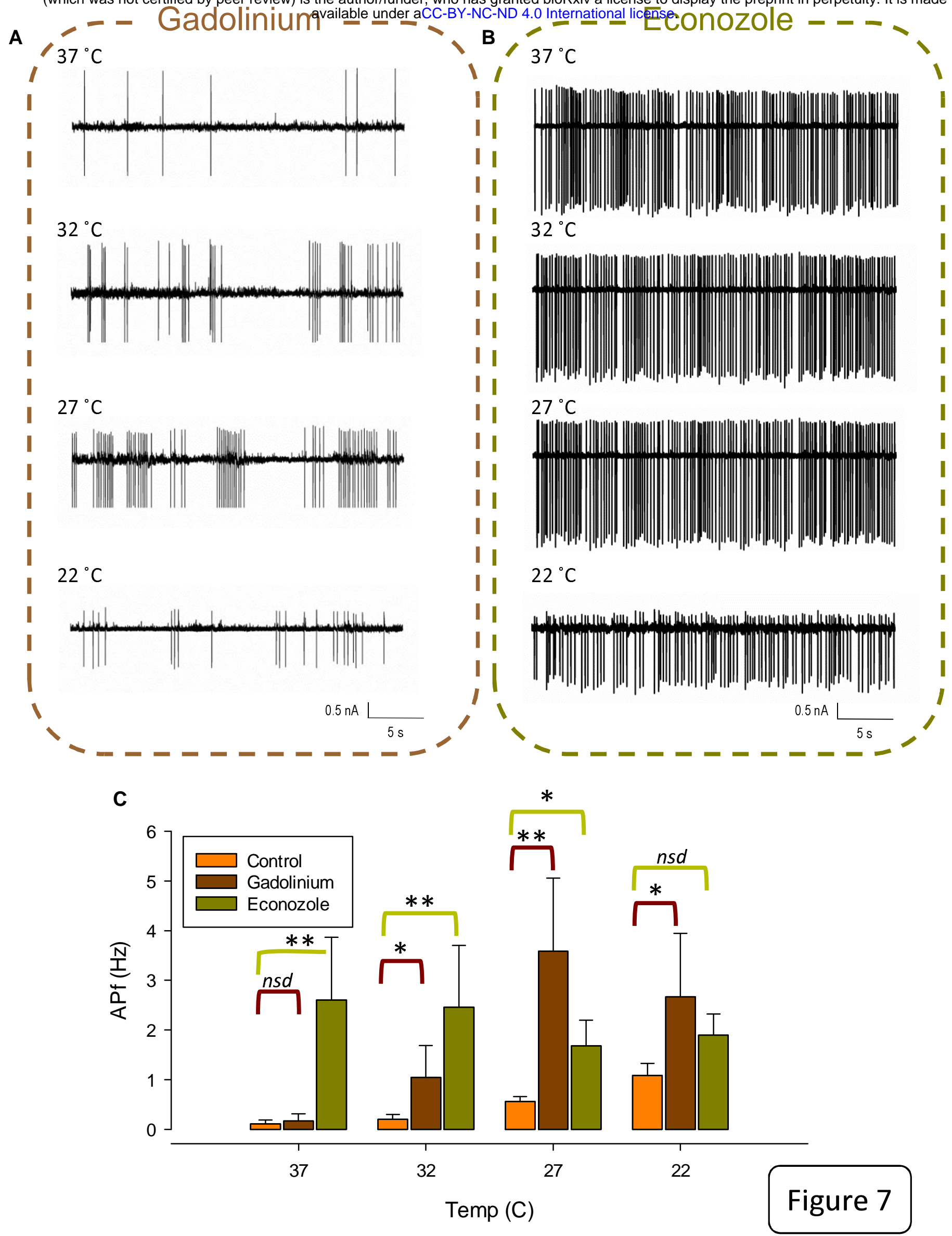
bioRxiv preprint doi: https://doi.org/10.1101/2022.01.26.477880; this version posted January 28, 2022. The copyright holder for this preprint (which was not certified by pegr review) is the author/funder, who has granted bioRxiv a license to display the preprint in perpetuity. It is made Supp Figure 1

A

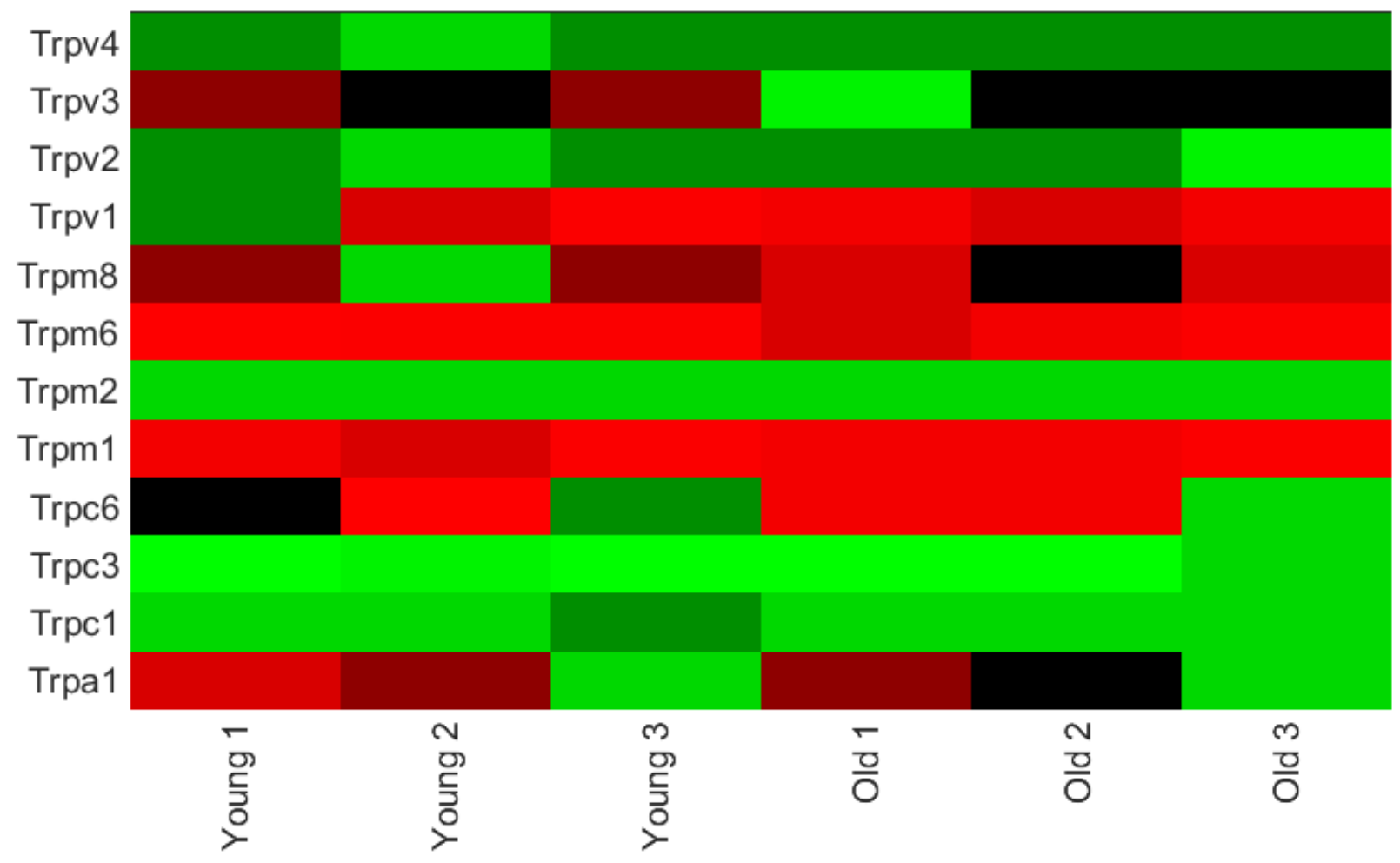

B

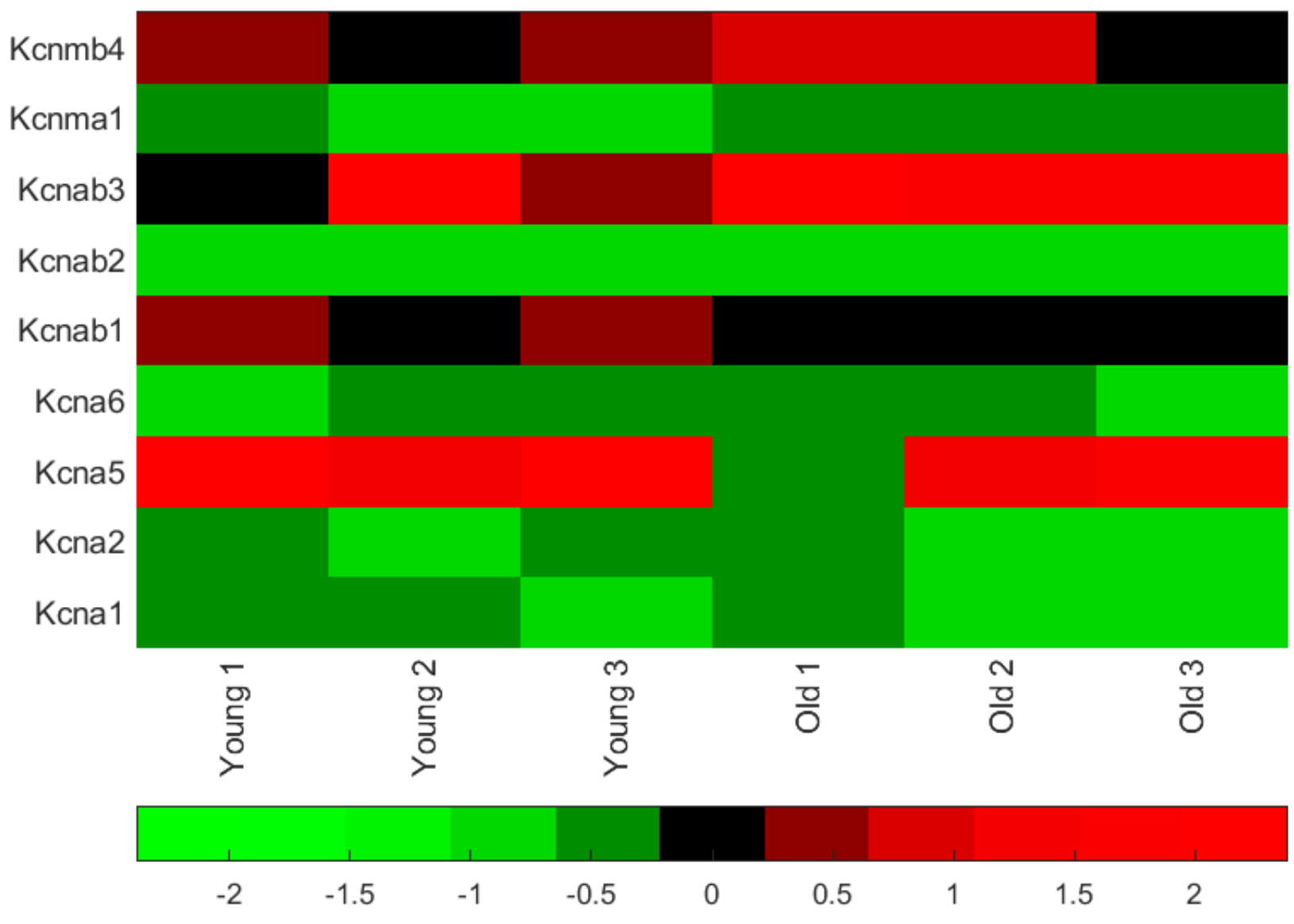


A

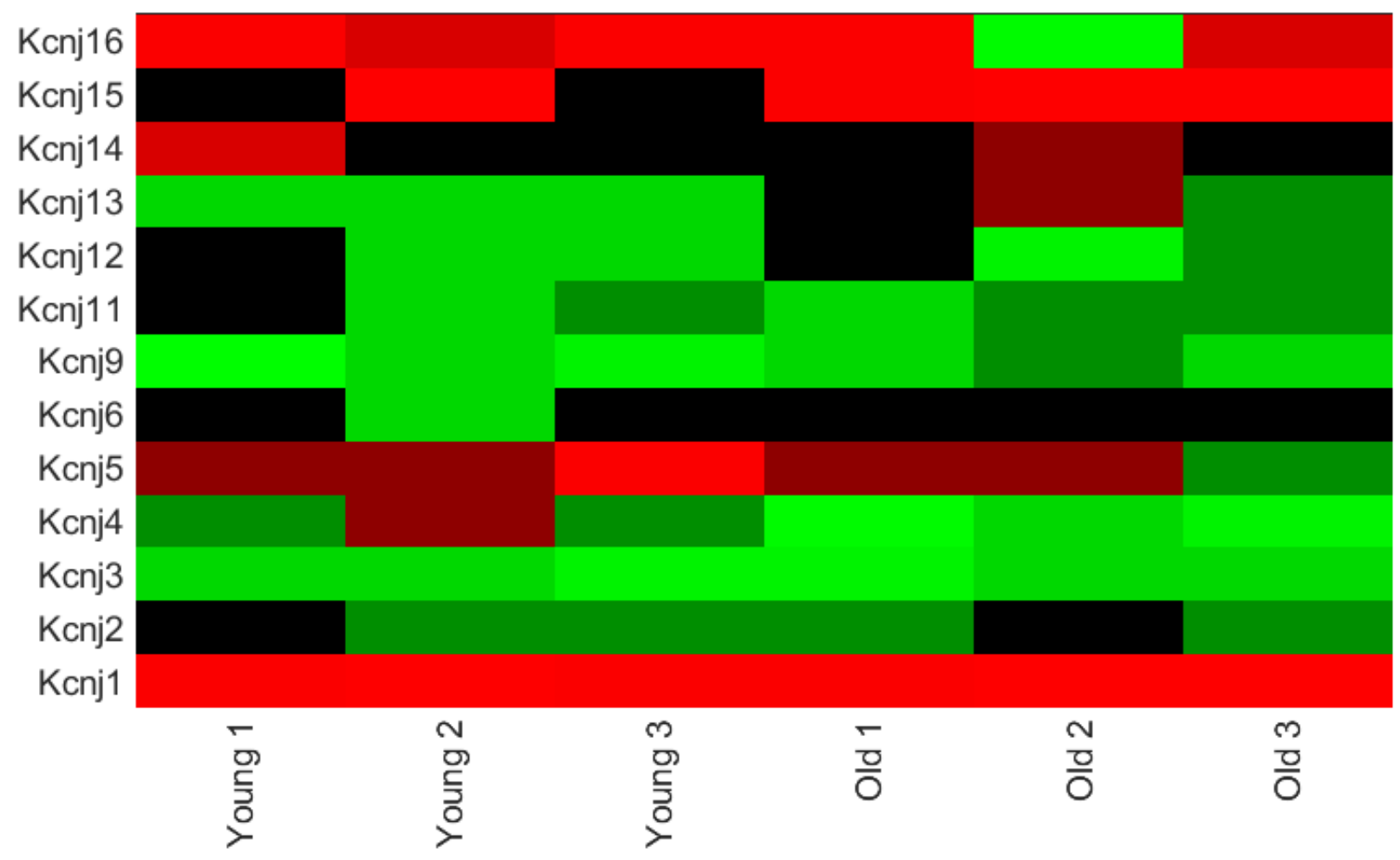

B
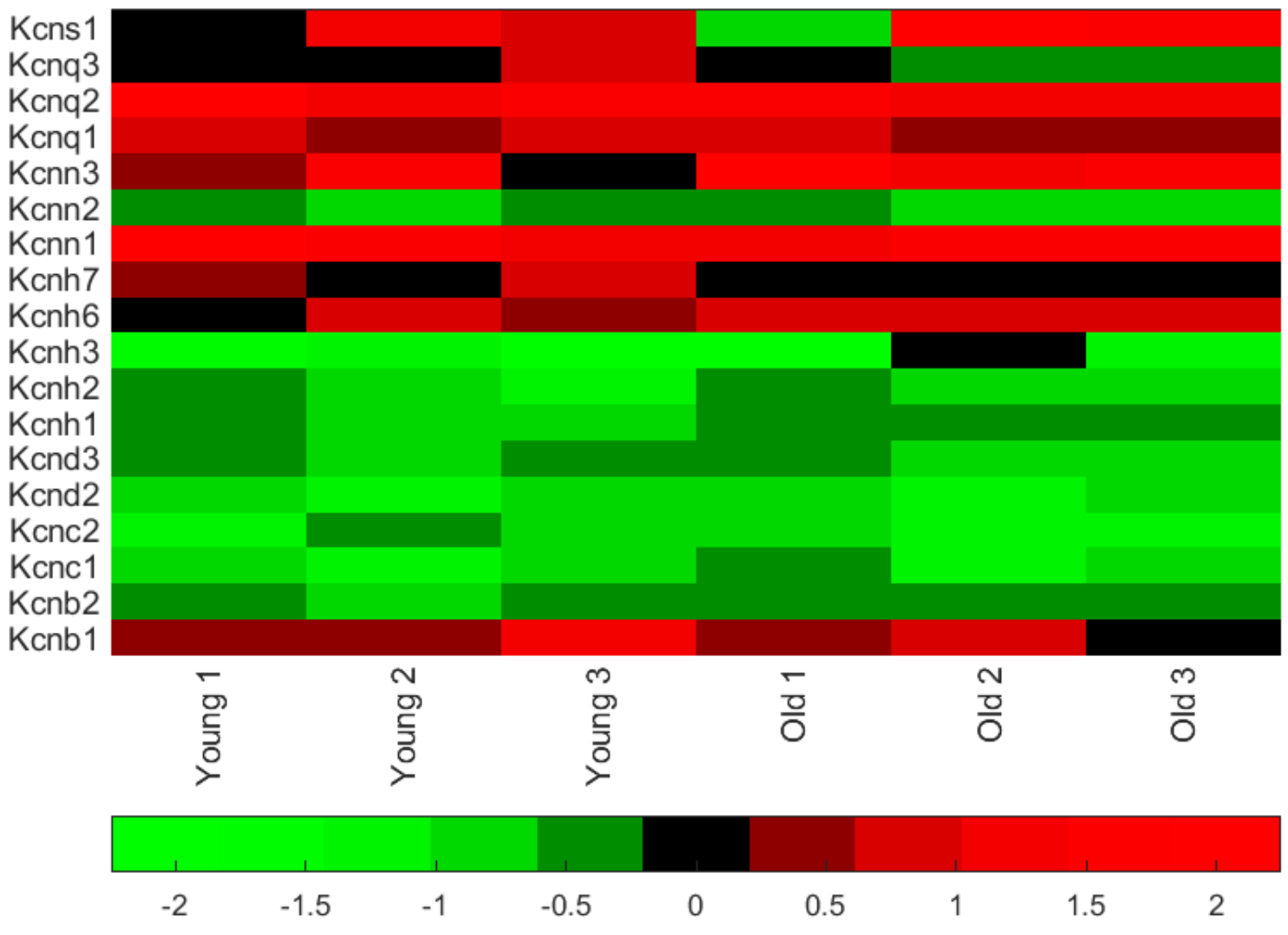

Supp Figure 3

A
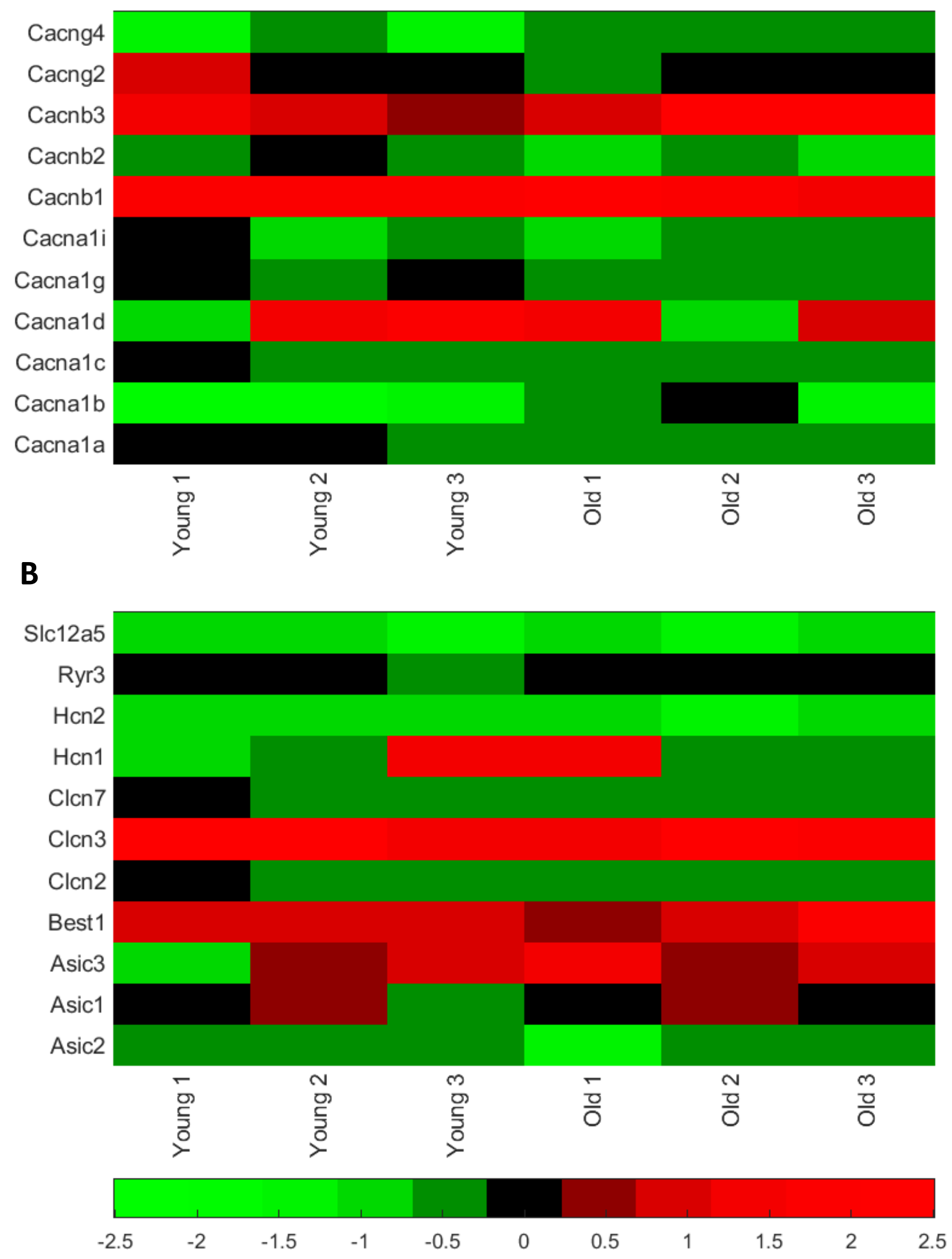